\title{
Intermediation in intermediation: triple helix innovation and intermediary legal organisation
}

René Reich-Graefe

\author{
Correspondence: rene.reich- \\ graefe@law.wne.edu \\ School of Law, Western New \\ England University, 1215 Wilbraham \\ Road, Springfield, MA 01119, USA
}

\begin{abstract}
Triple helix collaborations are evidence and example of larger 'post-postmodern' trends that have accelerated the convergence of once clearly established organisational dichotomies, in particular, market/hierarchy, private/public and forprofit/non-profit. The multiplex hybridity of triple helix collaborations creates unique challenges for the functional and, in particular, advance legal organisation and governance of their social welfare-oriented, quasi-entrepreneurial, quasi-regulatory innovation interactivity. Social innovation, resource valorisation and sustainability—constituting core normative underpinnings and objectives for triple helix models_-similarly affect the design and efficiency of hybrid firms that functionally and legally domicile triple helix intermediation. In an effort to help promote the emergence of sui-generis best practices in the intermediation of 'innovation in innovation' (Etzkowitz, Stud Sci 42(3):293-337, 2003a) triple helix projects, this article focuses on two interrelated aspects of triple helix hybridity which are less developed in the current literatures: First, based on a well-documented case study of a failed research group-firm hybrid within the University of Helsinki, it examines an institutionalised supra-helical, fourth-party intermediation model for triple helix networks and distinguishes such theoretical model from mere inter-helical selfintermediation in trilateral university-industry-government collaborations. Second, it hypothesises the possible association of supra-helical, fourth-party triple helix intermediation in application with blended private/public, for-profit/non-profit legal entities, in particular, only recently introduced hybrid legal organisations in the UK, the USA, and Canada. The main thesis developed under such dual focus is that the unique legal organisational design and domicile for triple helix intermediation, i.e. what this article terms the supra-helical mode 3 substructure, critically matters-both, for purposes of institutionalising efficient decision-making and governance equilibria in the promotion and operation of real-world triple helix projects and for controlling the agency and social costs of such advanced triple helix collaborations.
\end{abstract}

Keywords: Triple helix intermediation, Supra-helical intermediation, Intermediary organisations, Legal organisation, Hybrid legal entities 


\section{Resumen}

Colaboraciones en la Triple Hélice son evidencia y ejemplo de tendencias más grandes "post-posmodernos" que han acelerado la convergencia de dicotomías tradicionales en organizaciones de todo tipo. En particular, el mercado/jerarquía, privado/público y organizaciones lucrativas/sin-fines-de-lucro. La hibridación múltiple de colaboraciones en la Triple Hélice crea desafíos únicos para el funcionamiento de organizaciones jurídicas y de gobierno, en particular organizaciones de carácter asistencial, cuasi-empresarial, y de innovación cuasi-regulada. La innovación social, la valorización de los recursos y la sostenibilidad constituyen fundamentos básicos y objetivos normativos para la Triple Hélice. De forma similar afectan al diseño y la eficiencia de las empresas híbridas que acogen funciones de intermediación en la Triple Hélice.

En un esfuerzo para ayudar a promover la aparición de mejores prácticas de intermediación en la Triple Hélice, este artículo se centra en dos aspectos interrelacionados de la hibridación que no ha recibido mucha atención en la literatura: En primer lugar, se examina un modelo de intermediación de una cuarta persona, supra-helicoidal, y distingue ese modelo de la típica intermediación universidad-industria-gobierno. En segundo lugar, se plantea la hipótesis del posible role de organizaciones legales híbridas, subra-helicoidales; en particular aquellas de creación reciente en el Reino Unido, los Estados Unidos, y Canadá.

La principal tesis desarrollada es la de un diseño de la organización jurídica que alojará intermediación de la Triple Hélice. Este diseño lo denominamos en este artículo sub-estructura del Modo-3. Su importancia radica en la perspectiva crítica de los efectos de la institucionalización en la toma de decisiones y la gestión eficiente en la promoción y operación de proyectos de Triple Hélice del mundo real.

\section{Résumé}

Les collaborations de Triple Hélice sont la preuve et l'exemple des grandes tendances «post-postmodernes» qui ont accéléré la convergence des dichotomies organisationnelles déjà clairement établies, en particulier marché/hiérarchie, privé/ public, à but lucratif/à but non lucratif. L'hybridité multiple des collaborations de Triple Hélice crée des défis uniques au fonctionnement des organisations juridiques, et en particulier à celles déjà avancées, et à la gouvernance de leur interactivité quasi entrepreneuriale, quasi réglementaire et axée sur le bien-être social en matière d'innovation. L'innovation sociale, la valorisation et la durabilité des ressources constituant les fondements et les objectifs normatifs de base des modèles de la Triple Hélice - affectent de manière identique la conception et l'efficacité des entreprises hybrides qui fonctionnellement et juridiquement domicilient l'intermédiation de la Triple Hélice. Dans l'effort d'aider à promouvoir l'émergence de meilleures pratiques sui-generis dans l'intermédiation des projets de Triple Hélice de «l'innovation en matière d'innovation » (Etzkowitz, Stud Sci 42(3):293-337, 2003a), cet article se concentre sur deux aspects interdépendants de l'hybridité de la Triple Hélice qui sont moins développés dans la littérature. Tout d'abord, il examine un modèle supra-hélicoïdal institutionnalisé, quatrième partie de l'intermédiation des réseaux de la Triple Hélice, et fait la distinction entre un tel modèle théorique et l'auto intermédiation inter-hélicoïdale dans les collaborations trilatérales universitéindustrie-gouvernement. Et, deuxièmement, il émet l'hypothèse de l'association possible du modèle supra-hélicoïdal, quatrième partie de l'intermédiation de la Triple (Continued on next page) 
(Continued from previous page)

Hélice objet de l'article avec des organisations juridiques hybrides mixtes public/privé, à but lucratif/à but non lucratif en particulier, celles récemment créées au Royaume Uni, aux États-Unis et au Canada. La thèse principale développée est que la conception de l'organisation juridique de l'intermédiation de la Triple Hélice, que cet article dénomme « sous-structure supra-hélicoïdale mode 3 », est d'une importance critique, à la fois à des fins d'institutionnalisation d'un processus décisionnel efficace et de gouvernance équilibrée dans la promotion et le fonctionnement dans le monde réel des projets de Triple Hélice, tout autant que pour contrôler la gestion et les coûts sociaux de ces collaborations avancées de Triple Hélice.

\begin{abstract}
摘 要
三螺旋合作是更大的“后后现代”趋势的证据和例子。这一趋势已经加速了已清楚 建立的组织二分法的融合，特别是市场/等级制度、私人/公共、营利/非营利组 织。三螺旋合作的多重混合性产生了对功能的独特挑战,特别是推动法律组织及 其社会福利导向的、准创业的、准监管的创新互动的治理。社会创新、资源价 值增殖和可持续性构成核心,构成三螺旋模式规范的基 础和目标,同样影响在功能 和法律上属于三螺旋中介混成公司的设计和效率。为了努力帮助推动在“创新中 的创新" (Etzkowitz, Stud Sci 42(3):293-337，2003a) 三螺旋项目的中介方面属于自己 的最佳做法，本文重点关注现有文献中很少探讨的关于三螺旋混合性的两个相关 方面:第一，审查在三螺旋网络形成中超螺旋的、第四方中介模型，并区分这样的 一个理论模型和在大学-产业-政府三方合作中的仅仅跨螺旋的自我中介模型的不 同。第二,假定私人/公共、营利/非营利法律混合实体能用于超螺旋、第四方三 螺旋中介的联合，特别是最近才在英国、美国和加拿大推出的混成法律组织。 在这样的双重焦点下发展的重点是: 独特的法律组织的设计和三螺旋中介的注 册,也就是说,这篇文章要研究超螺旋模式3子结构, 最重要的目的有两个一——是 为了在促进和运行真实世界三螺旋项目过程使有效决策和治理平衡机构化;二是 为了控制这种先进三螺旋合作的中介机构和社会成本。
\end{abstract}

\section{Аннотация}

Трехспиральное сотрудничество является примером массовых постпостмодернистских тенденций, которые усилили сближение таких организационных дихотомий как рынок/иерархия, частный/публичный, коммерческий/некоммерческий. Многосторонняя гибридность тройной спирали формирует уникальные возможности для юридических организаций путем их вовлечения в социально-ориентированные, квази-предпринимательские и квазиуправленческие инновационные проекты. Социальные инновации, повышение ценности ресурсов и устойчивость формируют нормативную базу и цели трехспиральных моделей, оказывают влияние на форму и эффективность гибридных фирм, которые вовлечены в трехспиральное посредничество. В контексте вовлечения лучших практик посредничества в сфере «инноваций для инноваций» (Etzkowitz, Stud Sci 42(3):293-337, 2003а) в рамках трехспиральных проектов данная статья раскрывает два взаимосвязанных аспекта трехспиральной гибридности, которые недостаточно широко освещены в существующих публикациях. Во-первых, были исследованы институциональные (Continued on next page)
} 
(Continued from previous page)

супер-спиральные, четырех-акторные модели для трехспиральных сетей и выделена такая теоретическая модель как «внуриспиральное самопосредничество» в трехспиральных отношениях между университетом, бизнесом и государством. Во-вторых, выдвинута гипотеза о том, что возможные объединения в супер-спиральные, четырех-акторные системы могут способствовать внедрению посредничества в смешанных частных/ государственных, коммерческих/некоммерческих юридических организациях. В частности, в Великобритании, США и Канаде были недавно представлены гибридные юридические организации. Основной тезис, сформулированный в рамках данного исследования, заключается в том, что уникальная модель юридической организации и ее участие в трехспиральных взаимоотношениях приводит к образованию супер-спиральных форм, что, в частности, обеспечивает эффективность процесса принятия решений и управленческий баланс в действующих трехспиральных проектах, а также контроллинг организационных и социальных расходов.

\section{Resumo}

As colaborações da Hélice Tríplice são as evidências e os exemplos das maiores tendências 'pós-modernas' que aceleraram a convergência das dicotomias organizacionais, desde que claramente estabelecidas, em particular: mercado/ hierarquia, público/privado e com fins lucrativos/sem fins lucrativos. O múltiplo hibridismo de colaborações da Hélice Tríplice cria desafios únicos para o funcionamento e, em particular, da avançada organização jurídica e de governança da sua orientação para o bem estar social, quase empreendedora, quase regulatória da inovação interativa. A inovação social, a valorização dos recursos e a sustentabilidade - constituem os fundamentos normativos principais e os objetivos para o modelo da Hélice Tríplice- afetam de forma semelhante o design e a eficiência das empresas híbridas que funcionalmente e legalmente residem nas intermediações da Hélice Tríplice. Em um esforço para ajudar a promover o surgimento de melhores práticas sui-generis na intermediação da "inovação da inovação" dos projetos da Hélice Tríplice (Etzkowitz, Stud Sci 42(3):293-337, 2003a), este artigo foca em dois aspectos inter-relacionados de hibridismo da Hélice Tríplice que são menos desenvolvidos e comentados na literatura atual: em primeiro lugar, ele examina, um modelo institucionalizado supra helicoidal, quarta função do modelo de intermediação das redes da Hélice Tríplice e este modelo teórico de mera auto intermediação inter helicoidal em uma colaboração trilateral universidade - empresa - governo. E, em segundo lugar, propõe a hipótese da possível associação supra helicoidal, na quarta função da Télice Tríplice, na intermediação em organizações legais híbridos combinando público/privado, organizações legais com fins lucrativos/ sem fins lucrativos, em particular, e só recentemente introduzidas no Reino Unido, Estados Unidos e Canadá. A principal tese desenvolvida sob tal foco duplo é que o design único da organizacional legal e do domicílio da intermediação da hélice tríplice, ou seja, o que nos termos deste artigo o modo supra-helicoidal alicerça ambos em termos críticos para fins de institucionalizar a eficiência da tomada de decisão e equilíbrio da governança na promoção e operação de projetos da hélice tríplice no mundo real, e para controlar a ação e os custos sociais de colaborações hélice tríplice avançados. 


\section{Multilingual abstract}

Please see Additional file 1 for translation of the abstract into Arabic.

\section{Introduction}

The triple helix of university-industry-government relations has been described as a 'highly charged intellectual enterprise' (Todeva and Etzkowitz 2013). It may also be characterised as a highly charged organisational enterprise and intermediational challenge, in particular, for purposes of optimising advanced 'innovation in innovation' (Etzkowitz 2003a) triple helix hybrid organisations in the form of 'mode 3' (Carayannis and Campbell 2006, 2009, 2012) trilateral networks. Notwithstanding this characterisation and optimisation necessity, the functional and, more specifically, legal organisation of real-world triple helix intermediation projects is still in early stages of ad hoc experimentation and improvisation. In other words, triple helix intermediation, in current application, remains both under-planned and under-institutionalised. Similarly, the intermediation of triple helix trilateral networks remains significantly understudied (Metcalfe 2010; Suvinen et al. 2010). Given the 'previously buffered ... space between firms and campuses' (Metcalfe 2010: 504) and the continued institutional isolation of each of the university-industry-government helices, it further appears that the design and provision of efficient legal intermediation practices and organisations should be of paramount importance for purposes of transcending the long-standing and pervasively practised institutional separateness and resistance to innovate and transform (see Tuunainen (2002)) among the helices, as well as for developing the institutional foundations of a sustainable intra-, inter-and, in particular, supra-helical intermediation infrastructure. It is this facilitating and reconciling intermediary infrastructure-including, its chosen legal premises and entity-level organisation-which has to continually and simultaneously effectuate a large and complex multitude of middle-position team-production equilibria among the helices in order to provide the cohesion, stability and synergy necessary for the long-term sustainability and innovation gains of real-world triple helix projects (see van Lente et al. (2003)).

Accordingly, this article posits that hybrid triple helix organisation and its intermediation require institutionalised coordination, centralisation and control functions to critically support formative and adaptive decision-making and governance processes in applied triple helix projects. Traditionally, such functions-often cost-prohibitive, thus, unavailable ex ante through transaction cost-efficient market ordering in multi-constituent ventures-have been concentrated within a firm (Coase 1937) or have otherwise been undertaken through a network's hub or apex (Todeva 2006). In both such organisations, decisional hierarchies and vertical control processes are ultimately paradigmatic institutional orders practised and sustained through a consensus of affected stakeholders and constituencies (Benner and Sandström 2000) as well as through the exercise of governmental authority and regulatory, i.e. legal, intervention (Leydesdorff 2000; Todeva 2010). This article, therefore, further posits that the functional and, in particular, advance legal design of 'intermediating organizations' (Metcalfe 2010) critically matters for purposes of optimising triple helix processes and their innovation productivity, thus, for achieving 'the optimal rate of R\&D investment to maximize productivity growth' (Galindo et al. 2011: 10; see also Garrett-Jones et al. (2013: 81)). Thus, in an effort to support and inform the evolution of sui-generis supra-helical best practices for 'innovation in innovation' (Etzkowitz 2003a) triple helix projects, this article focuses on two interrelated aspects of triple helix hybridity which are less developed, if not, neglected (Suvinen 
et al. 2010; Howells 2006; van der Meulen et al. 2005) within the current triple helix literature as well as the larger knowledge intermediation and innovation intermediation literatures. First, based on a well-documented case study of a failed research group-firm hybrid within the University of Helsinki (Tuunainen 2001, 2002, 2004, 2005a, b, c), an organisational model aimed at institutionalising supra-helical, fourth-party (i.e. beyond mere inter-helical, threeparty) intermediation is proposed and examined for purposes of optimising trilateral university-industry-government networks. Second, the possible association of such suprahelical, fourth-party triple helix intermediary organisations with blended private/public, forprofit/non-profit legal entities is analysed in first, foundational terms-in particular, as regards only recently introduced hybrid legal organisations in the UK, the USA and Canada.

\section{Triple helix intermediation and legal organisation}

Triple helix intermediation may be described as the co-alignment (i.e. the process of bridging, attuning, matching, bundling and, eventually, inter-braiding) of the specific research knowledge, technology, creativity and other innovation assets, as well as of the specific participatory interests, of each of the university-industry-government helices. Triple helix intermediation facilitates and implements the genesis of sui-generis and symbiotic accumulative, concentrative and diffusive innovation processes (see Bellgardt et al. (2014); Bathelt et al. (2011))—sui generis and symbiotic since none of the helices is selfsufficient in this regard (Johnson 2008). Thus, triple helix innovation can also be characterised as an exercise in team production where innovation processes are generated codependently and are only possible through the respective sunk investments and the concerted productive activity of all three helices. In result, triple helix intermediation fosters and contributes to overall social investment and innovation outcomes, i.e. to the creation of public goods (Todeva 2013: 273). Notwithstanding such central role of triple helix intermediation in fully-integrated 'mode 3' (Carayannis and Campbell 2006, 2009, 2012) university-industry-government 'innovation in innovation' triple helix projects (Etzkowitz 2003a; Etzkowitz and Leydesdorff 2000), Bellgardt et al. (2014: 12) have recently concluded that '[1]ittle attention is paid to intermediaries in the triple helix approach.' Similarly, Metcalfe (2010: 504) has found the fully-integrated trilateral networks of the triple helix to be 'understudied,' prompting her to critically explore and model 'the role of external organizations in the formation of AIG ties.' Notwithstanding the relatively small sample of directly applicable scholarship, more developed literatures tackling intermediation and intermediary organisation exist within many disciplines (Landry et al. 2013; Todeva 2013) - in particular, for current purposes, in the related research fields of innovation and technology transfer intermediation (Boon et al. 2011; Dalziel 2010; Dalziel and Parjanen 2012; Gassmann et al. 2011; Håkanson et al. 2011; Hoppe and Ozdenoren 2005; Howells 2006; Kivimaa 2014; Klerkx and Leeuwis 2008; Kodama 2008; Lichtenthaler and Ernst 2008; Pollard 2006; Sieg et al. 2010; Shohet and Prevezer 1996; Stewart and Hyysalo 2008; Suvinen et al. 2010; van der Meulen et al. 2005; van Lente et al. 2003; Villani et al. 2016) and knowledge intermediation (Cantù et al. 2015; Parker and Hine 2014; Schlierf and Meyer 2013; Wright et al. 2008; Yusuf 2008). Even here, however, authors have pointed out that '[d]espite their obvious presence, ... innovation intermediaries have received little attention in the theoretical intermediation literature' (Hoppe and Ozdenoren 2005: 484) so that 'relatively few systematic analyses of their functions' (Suvinen et al. 2010: 1366) are available today (see also van der Meulen et al. (2005: 2)). 


\section{Research methodology}

The article approaches the institutionalisation of triple helix intermediation from a systemstheoretical perspective rather than through empirical investigation-although it also includes an analysis and discussion of Tuunainen's well-documented qualitative research and case study of a failed 'attempt by [a university research] group to operate as a research group-firm hybrid entity within the University of Helsinki in 1998-2000' (Tuunainen 2004: 43; see also Tuunainen (2001, 2002, 2005a, b, c)). The analysis and discussion of the case study then serves as a jumping-off point to introduce a bifurcated model of triple helix intermediation and its legal organisation in order to supplement existing theoretical and empirical research on the former and to make a first, small effort at compensating for the current scarcity of research on the latter. In general terms, it is argued that the study of triple helix intermediation and its institutionalisation within the triple helix should differentiate between the process of intermediation (both, external, at the overall triple helix level and, internal, at the intermediation level itself-i.e. together, the relational realm of intermediation) and the organisation of intermediation (both, on the level of the intermediator, i.e. the intermediary actor, and on the level of such intermediator's own legal organisation-i.e. together, the institutional realm of intermediation). Based on this theoretical modelling and exploration, the overall organisation of triple helix intermediation is, thus, described more precisely as an overlay of four interdependent and interactive organisational spheres as well as in terms of a threefold organisational shift from inter-helical, ad hoc and self-administered to supra-helical, institutionalised and fourth-party administered intermediation. The research is exploratory and theoretical, discussing the legal organisational dimension of institutionalising triple helix intermediation in a more systematic, functional analysis as well as through a broader normative lens. At its early stage, it is not intended to review the entire field in a meta-analysis of available empirical evidence for what the current legal institutionalisation practices in triple helix intermediation indeed are. However, given its findings that triple helix intermediation is significantly understudied in theory as well as pervasively under-planned and under-institutionalised in application, this study also formulates first, tentative assumptions as to how intermediation in real-world triple helix collaborations should be organised (in particular, from a legal perspective) and then speculates on practical avenues in this regard by reviewing the hybridisation of modern legal organisations among market/hierarchy, public/private and for-profit/non-profit boundaries.

\section{Brief literature review}

Etzkowitz (2002: 122, 2003a: 301, 2003b: 113; see also Etzkowitz et al. (2010: 88); Etzkowitz and Ranga (2011: 141-142); Ranga and Etzkowitz (2010: 8); Todeva and Etzkowitz (2013: 11)) discusses the role of intermediation in triple helix research only indirectly and rather at the periphery when he describes, as the third stage of the emergence of the triple helix, the '[c]reation of a new overlay of trilateral networks and organizations from the interaction among the three helices [and that] [s] uch groups typically form to fill gaps in an innovation system by "brainstorming" new ideas' (2003a: 301). Similarly, Ranga and Etzkowitz (2013: 250) mention, in passing, 'intermediary and transfer organizations and networks-[forming] the innovation space-that are the breeding ground of new knowledge-based clusters.' It appears that the organisations, groups and networks which Etzkowitz (2002, 2003a, b) and Ranga and Etzkowitz (2013) have in mind as being interstitial and intermediary-in that they are '(intentionally) situated between the state, industry, and higher education' (Metcalfe 
2010: 507) — will, at some crystallisation point of inter-helical relational saturation, spontaneously and organically 'spring into existence' for purposes of developing and promoting the cognitive, spatial, organisational and social innovation proximity (Bellgardt et al. 2014; Cantù et al. 2015; D'Este et al. 2012; Villani et al. 2016; Zhou 2014) required among the three stakeholder-helices. Accordingly, these organisations, groups and networks come to constitute the core 'agents whose task is to combine the industry-university-government structure together, thereby supporting the development of Triple Helix structures' (Suvinen et al. 2010: 1367). Notwithstanding such critical agency role (and its attendant agency and social cost dilemmas), almost none of the current triple helix/innovation/knowledge intermediation literature appears to focus on the legal and regulatory details of designing and institutionalising efficient decision-making and governance equilibria in real-world triple helix intermediation projects. As Garrett-Jones et al. (2013: 80) have pointed out, the triple helix model, among other innovation models, is limited because [it] fail[s] to explain how the new cross-sector R\&D organisations are best structured, managed and sustained and how the process of renegotiation takes place between the [collaborative] centres and the member institutions'-in particular, if one also assumes that asset specificity (Williamson 1975) applies to the production of triple helix innovation gains and that long-term triple helix innovation is characterised by a continual (and to be intermediated) struggle over, thus, costly renegotiation of, the allocation and distribution of team-produced innovation gains.

Recent research that discusses-though only tangentially-the legal setup and formalised governance structures of certain intermediary organisations can be found, for example, in Fernández-Esquinas et al. (2012), Garrett-Jones et al. (2013), Hepburn and Wolfe (2014), Johnson (2008), Klerkx and Leeuwis (2008), Landry et al. (2013) Pinto et al. (2015), and Weisz et al. (2013). Nevertheless, none of such literature addresses the legal organisational dimension of institutionalising triple helix intermediation in either a systematic fashion (i.e. reviewing the field for empirical evidence of what the current practices are) or through a broader normative lens (i.e. discussing how innovation intermediation should be organised, in particular, from a legal organisational perspective). In order to provide some quantitative support for the current research scarcity on this subject, a citation/search analysis conducted on 21 June 2016 using Google Scholar yielded the following results: searching for (1) 'triple helix' 'choice of entity', (2) 'triple helix' 'choice of legal entity', (3) 'triple helix intermediation' 'legal organisation' (i.e. British spelling) and (4) 'triple helix intermediation' 'legal organization' (i.e. American spelling), in each case, returned not a single matching article. When searching for (5) 'triple helix' 'legal organisation' (British spelling) and (6) 'triple helix' 'legal organization' (American spelling), Google Scholar produced 5 and 15 matches, respectively. Of the five 'legal organisation' matches (which already counted one article twice, i.e. as two matches rather than one), only two articles mention at all that legal organisation is relevant in the broader context of triple helix innovation. However, each of those two matches does so only once and only in mere passing (Arvanitis 2001; Pinto et al. 2015). Of the fifteen 'legal organization' matches returned by Google Scholar, three articles discuss, in very basic and rudimentary terms, that legal organisation is generally relevant for research collaboration (Fuglsang and Eide 2012; Rivers 2010; Wagner 2007). The remaining 12 articles make only cursory mention of 'legal organization' and only in contexts other than triple helix innovation. Similar full-text searches in the 
HeinOnline Law Journal Library (providing access to more than 1600 law and lawrelated periodicals) on 21 June 2016-applying the same six search queries used above for Google Scholar-produced not a single matching result. It may, therefore, be safely argued that the legal organisation of triple helix intermediation, in both theory and practice, currently constitutes a mere afterthought within both the social sciences and the legal literatures.

\section{Differentiating triple helix intermediation and legal organisation}

At the heart of triple helix innovation lies the realisation that intra-helical knowledge is an inter-helical innovation asset. As with every other asset, the valorisation of intra-helical knowledge through inter-helical triple helix research productivity ultimately requires commodification. The commercial value of a commodity depends entirely on its marketability which, in turn, entirely depends on its transferability-either in toto or as regards its innate utilisation and consumption entitlements. Transferability is impossible without the legal (hence, enforceable) recognition and protection of ownership, control and disposition rights that make the commodity a commodity in the first place (Todeva 2005, 2013). In other words, both marketable property rights in knowledge assets and the legal (and, often, exclusive) ownership, control, utilisation and disposition rights vested in a property holder (i.e. asset owner) need to be institutionally recognised and protected by law ex ante of any (ability of) valorisation. If the organisational and institutional design (of triple helix intermediation) indeed matters for purposes of the performance, growth and sustainability of firms, 'quasi-firms' (Etzkowitz 2003b) and other (quasi-)entrepreneurial ventures (including real-world triple helix projects) (Fitjar et al. 2014; Garrett-Jones et al. 2013; Klerkx and Leeuwis 2008; Roberts 2004), then law, in particular, the legal organisational setup and control of such firms and other ventures, constitutes a crucial, indeed, foundational ingredient of their overall institutional governance and efficiency equilibria (La Porta et al. 2000; Maughan and McGuinness 2001). Law and its organisational tools institute both the individual enabling structures and the global infrastructure for innovation and entrepreneurship to occur and to create economic value. Law and legal organisation also decide to whom the economic benefits of innovation and entrepreneurship activity will accrue. The creation and distribution of social welfare gains qua law, thus, also drive innovation and entrepreneurship intermediation. Here, the productive focus may be more on the provision of value-added innovation services (Wright et al. 2008: 1206) rather than on the development of innovative goods or technologies. Still, for intermediation (and intermediary knowledge and services) to constitute an innovation asset-thus, for a market for intermediation services to exist in the first place-the law has to similarly recognise such services as a valuable commodity, has to support their marketability in predictable and enforceable contractual buy-sell or licensing transactions and has to ultimately decide to whom the economic gains of intermediation activity will accrue-both, direct gains (i.e. financial income) and indirect gains (i.e. new innovation assets created through intermediated team productivity). To paraphrase Tuunainen (2005b: 285), the triple helix and its intermediation may 'be conceptualized in terms of historically-evolving local activities where researchers [, firms and government agencies] make use of heterogeneous sets of cultural resources [including legal resources] to achieve their particular objectives.' Given that a particular society's provision of legal resources is neither accidental nor ad hoc-in other words, that such provision has to be planned, 
organised, structured and specifically legislated ex ante-there are two possible avenues for the legal support and organisation of triple helix intermediation: either a given legal jurisdiction can adapt existing legal property and governance structures to accommodate and recognise triple helix innovation assets (as well as their ownership and control), or the same jurisdiction can adopt new, sui-generis property and governance structures by legislative action in order to properly domicile and organise such assets as public goods.

At the current stage of the legal institutionalisation of triple helix intermediation, this 'adapt-or-adopt' strategy appears to default, ubiquitously and in its entirety, to the adaptation of existing legal structures. Notwithstanding the obvious legal differences among national jurisdictions in this regard, pre-existing and one-size-fits-all (thus, non-strategically employed) legal entity forms appear to be universally utilised in realworld triple helix collaborations, by either accident (i.e. statutory default) or design, in order to serve as intermediary organisations. For example, intermediary organisations have been described in this regard as 'foundations, associations, consortia, independent research centers (including research parks), or special interest groups.' (Metcalfe 2010: 507; see also Dalziel and Parjanen (2012: 118); Ranga and Etzkowitz (2013: 245)). All of those organisations, in the real-world practice of intermediation organisations, may already constitute different types of legal entities (for example, foundations and associations), or they will otherwise be formed and institutionalised with very different legal, governance and decision-making attributes (for example, R\&D consortia may be organised as contractual, hence, unincorporated joint ventures, for-profit partnerships or corporations, non-profit foundations or associations, as alternative business structures, in the form of hybrid for-profit/non-profit corporations, etc.). And the very same functional type of organisation may be structured in a completely different legal manner in different jurisdictions. For example, the leading national, publicly-funded technology and innovation centres in the UK, the USA and Germany-the Catapult Centres, the National Network for Manufacturing Innovation, and the Fraunhofer-Gesellschaft zur Förderung der angewandten Forschung (Fraunhofer-Society), respectively-are each organised in a completely different legal manner (for details, see Hepburn and Wolfe (2014)):

In the UK, the Catapult Centres were created by the national innovation agency, the Technology Strategy Board, as a regulatory, public-sector network of elite technology and innovation intermediaries in which each Catapult Centre is an independent legal entity organised as a private company limited by guarantee-a type of corporate entity regularly used for charities (i.e. non-profit organisations) under UK law. In the USA, the National Network for Manufacturing Innovation was established as a federal governmental network of national research institutes and is operated by the Advanced Manufacturing National Program Office within the National Institute of Standards and Technology of the US Department of Commerce. Each research institute, a so-called Institute of Manufacturing Innovation, is organised as a public-private membership organisation, preferably in the form of a public-private consortium, and is led by an independent, not-for-profit institution (for example, an industry association or a university). According to the public procurement rules applicable to the formation of each national research institute, each institute, as a public-private consortium, can either be organised as an incorporated consortium (i.e. as a separate legal entity, incorporated or formed under the laws of a US state or territory or under the laws of any foreign country) or as an unincorporated consortium (i.e. as merely a 
contractual, joint venture-type arrangement without separate legal personality, governed by either US or foreign law), in which latter case 'a collaboration agreement, commonly referred to as the articles of collaboration, [is required and] should discuss ... the consortium's[] [m]anagement structure; [m]ethod of making payments to consortium members; [m] eans of ensuring and overseeing members' efforts on the project; [p]rovisions for members' cost sharing contributions; and [p]rovisions for ownership and rights in intellectual property developed previously or under the agreement' (US Department of Energy 2015: 22-23). Finally, in Germany, the Fraunhofer-Society currently operates an applied research network of 67 institutes and research units in which each such institute or unit-in contrast to the legal organisation of their respective counterparts in the UK and the USA-is not set up with its own, separate legal status (either entityor contract-based) but is operated and managed merely as a functional sub-unit of the overall network, i.e. the Fraunhofer-Society itself. And unlike the regulatory, public-sector network and governance structures used in both the UK and the USA, the Fraunhofer-Society is its own private-sector, non-profit entity: a eingetragener Verein, i.e. a registered association under German law which is widely used for non-profit organisations.

In addition, it should be noted that even within the same national innovation jurisdiction, the same functional type of intermediary organisation may often be structured and domiciled through very different legal entity forms-simply because there are so many different legal forms to choose and adapt from ad hoc. To name a few options in this regard: should a particular triple helix intermediary organisation be an unincorporated association, a foundation, a trust, a non-profit corporation/company, a forprofit business corporation/company, a for-profit general partnership, a contractual joint venture or consortium (i.e. without separate legal personality), a cooperative or a for-profit/non-profit hybrid corporation/company (for example, in the United Kingdom, a community-interest company)? The current variety in legal organisation may be inevitable given the adaptation default strategy on the one hand and the fact that intermediary legal organisations are tasked with domiciling a wide spectrum of possible real-world triple helix intermediation activities on the other hand. However, even when 'explored independently', taking into account that 'each type of intermediary organization ... will have unique characteristics' (Metcalfe 2010: 507; see also Landry et al. (2013: 431); Pollard (2006: 150)), all of the above types of legal entities (and many more) are pre-existing and generic tools of private/public, for-profit/non-profit ordering for purposes of partitioning and recognising enforceable separations and legal spheres of rights, responsibilities and assets. It may, therefore, be concluded that the legal organisation of real-world triple helix intermediation projects still occurs in very early stages of ad hoc experimentation and improvisation. Thus, it may also be claimed that current triple helix collaborations and their intermediation are both under-planned and under-institutionalised and that matters would generally benefit from a more robust academic discussion as regards (i) the adoption of new, sui-generis types of blended, thus, hybridised private/public, for-profit/non-profit legal organisations in order to specifically and exclusively organise triple helix innovation and its intermediation and (ii) at a minimum, the adaptation of existing legal entity formats in order to allow for the specific creation and tailoring of custom-made triple helix intermediary organisations. 


\section{Hybrid firm case study}

The 'building [of] and participation in triple-helix-type networks is often timeconsuming and costly' (Fitjar et al. 2014: 2), in particular, given the 'risks associated with expensive R\&D' (Johnson 2008: 497). Triple helix intermediation is, thus, generally intended to 'reduce search costs and bargaining costs for the firms and universities that are seeking collaboration partners' (Kodama 2008: 1226; see also Todeva (2013: 263)) and to mitigate overall uncertainty about the profitability of collaboration (see Hoppe and Ozdenoren (2005)). Accordingly, the underutilization of advance legal planning tools in, and the resultant under-institutionalisation of, triple helix intermediation must be regarded as both costly and inefficient-in particular, when the specific triple-helix project in question ultimately and prematurely fails. In every real-world triple helix network, there will come a juncture where inter-helical ties thicken and organisational complexity increases, where the distribution of future innovation gains from network activity (and, therefore, the prior individual investment of non-shared productive resources by each helix in support of such activity) begins to matter to network participants, and where, in result, any heretofore decentralised, ad hoc and diffuse network activity begins to require a certain, additional degree of permanent and systematic coordination, centralisation and control in its deployment of scarce network and network-participant resources (Etzkowitz 2003a; see also Etzkowitz (2002); Todeva (2014)). Such coordination, centralisation and control functions by an intermediary network hub necessitate both planning and conscious 'interjection'. For example, cooperative research centres (CRCs) 'that bring together universities, industries and government agencies in the context of strictly commercial research' (Tuunainen 2005b; see also Fernández-Esquinas et al. (2012: 3); Garrett-Jones et al. (2013: 80); Slaughter and Leslie (1997: 149-151)) do not 'spring into existence' spontaneously. And their functional and organisational interjection among and between the university-industrygovernment helices should be carefully planned and executed-in particular, through (i) the legal institution of a CRC entity (or of multiple entities, as the case may require) separate from the sponsoring helices and (ii) the advance legal ordering of the rights and responsibilities of the promoting helices as CRC stakeholders and (most likely, also) owners of the respective CRC entity (or entities) (see Garrett-Jones et al. (2013)). In this regard, the well-documented and well-developed case study of the parallel academic and entrepreneurial endeavours of a biotechnology research group at the University of Helsinki in Finland discussed by Tuunainen (Tuunainen 2001, 2002, 2004, 2005a, b, c) may serve as a useful, real-life example of the steep cost and inefficiency of under-planned and under-institutionalised innovation intermediation:

In August 1998, the 'Applied Plant Biotechnology Research Group, which operated in the Department of Plant Production at the University of Helsinki, Finland, from 1990 until the autumn of 1999' (Tuunainen 2004: 32) (hereafter, the 'Research Group') established its own biotechnology start-up company as a separate spin-off business (Tuunainen 2005a: 180-181) (hereafter, the 'Spin-Off Company'). It thereby also created a 'hybrid firm' (Etzkowitz et al. 2000: 320) or 'hybrid community' (Tuunainen 2002: 37; see also Gibbons et al. (1994: 37-38)) that 'combin[ed] the academic research group and the emergent spin-off company ... with an aim of pursuing both academic research and commercial development all at once' (Tuunainen 2002: 50) and 'simultaneously in two distinct environments, the research laboratory on the [university] campus and the spin-off company 
somewhere else' (Tuunainen 2005a: 175) (hereafter, the 'Hybrid Firm'). The Research Group was led by a professor with broad international expertise in plant biotechnology who was actively recruited from abroad, together with her established group of researchers, by the University of Helsinki (Tuunainen 2005a: 170-180) (hereafter, the 'Research Leader'). The Research Group 'was the first in Finland to apply modern biotechnology to improve field crop plants [and] was ... strongly networked with relevant plant-biotechnology research groups throughout the world' (Tuunainen 2005a: 180; see also Tuunainen (2001: 86)). As is typical for hybrid firms (Etzkowitz et al. 2000: 320), the Research Leader and many other academic staff members of the Research Group concurrently held positions at, and worked for, the Spin-Off Company. Indeed, the Research Leader 'and three of her graduate students became shareholders of the [the Spin-Off Company] while remaining at the same time members of the [university department's] faculty' (Tuunainen 2005a: 181). Prior to the creation of the Hybrid Firm in August 1998, the Research Leader also served as her university department's chair, but, 'simultaneously with the founding of the [Hybrid Firm]' (Tuunainen 2005a: 182), she 'stepped down from the department chair in response to an administrative plan to reform the departmental structure within the faculty, which she strongly opposed' (Tuunainen 2005a: 205). The newly elected department chair, a professor of agroecology (hereafter, the 'New Chair'), immediately changed the Research Leader's 'informal and managerial approach towards administration', emphasised 'correct procedures' and 'departmental democracy' in the conduct of the faculty and the department's administrative procedures (Tuunainen 2005a: 182), 'insist[ed] on accounts from the [Research Leader] concerning the [Spin-Off Company]' (Tuunainen 2005a: 187), and, thus, significantly implicated the Research Group's continued 'ability to combine academic work with business' (Tuunainen 2005a: 182). At the same time, regulations concerning business activities within the University of Helsinki remained 'weak' and 'very few', leaving the university 'quite free to take its own stand towards commercialization' (Tuunainen 2005a: 182-183). While a 1967 Finnish law on inventions made by employees during the course of their employment 'granted the right to patent research results to university scientist themselves [without even imposing] an obligation to inform the university administration, the University of Helsinki, during the late 1990s, "launched a new procedure [according to which all intellectual property rights of university scientists should] be transferred from individual academics to the university institution' (Tuunainen 2005a: 183).

Faced with the objective ambiguity of the novel Hybrid Firm situation and the subjective ambivalence of the main parties involved-i.e. the Research Leader on the one hand (simultaneously representing interests of herself, her academic Research Group and her SpinOff Company, in particular, with regard to the intellectual property claimed by, or on behalf of, the Spin-Off Company (Tuunainen 2002: 46)) and the New Chair on the other hand (representing the university department, remaining accountable to faculty deans and central university administrators, and attempting to define and institute proper boundaries between official departmental research and its commercialisation in the absence of either university regulations, legislative standards or, at least, contractual arrangements 'on the involvement of academic personnel in business activities that were related to their university duties' (Tuunainen 2005a: 185)) - the Hybrid Firm quickly folded. Tuunainen (2005a: 187) identifies four major interest spheres and attendant interest divergences-between the university department, represented by its New Chair, and the Spin-Off Company, represented 
by its main stakeholder, the Research Leader-that contributed to the 'gradually deteriorating conflict' within the Hybrid Firm and to its eventual demise: '1) the bureaucratic authority of the [New Chair], 2) the allocation of teaching loads between faculty members, 3) the ownership of research tools and materials and 4) the intellectual property rights of the [Research Group]'s researchers' (see also Tuunainen 2002: 51, 2004: 56, 2005b: 291; see generally Wright et al. (2008: 1213-1214)). As a result, in late 1999, two new boundaries were established by the university, namely, a 'social and [a] spatial [one], by means of which the [Research Group]'s business activity was separated from its public-sector research' (Tuunainen 2005b: 291; see also Tuunainen (2005a: 199); see generally Etzkowitz (2003b: 117)). As a first step, the Research Group 'was relocated' (Tuunainen 2005a: 197): 'its academic research projects [were transferred] to the University of Helsinki's Institute of Biotechnology' (Tuunainen 2004: 32), i.e. away from the department to 'a different organizational unit of the university ... [o]perating in a science park [with a] primary focus ... on high-quality academic research and postgraduate education' (Tuunainen 2005a: 197). Meanwhile, the SpinOff Company 'was establishing its facilities under the auspices of the university's business incubator' (Tuunainen 2004: 32), thus, being 'sealed away from the university's core academic units to more peripheral organizational position' (Tuunainen 2005b: 291). Indeed, a new 'collaboration agreement was concluded between [the Spin-Off Company], the [Research Group] and the [Institute of Biotechnology in which] an attempt to "deconstruct" the hybrid was made, that is, its public and private parts were separated from each other [and] the mixed roles of researchers-entrepreneurs were abandoned' (Tuunainen 2005a: 198-199). In the Research Leader's opinion, these new social and spatial boundaries 'had the dysfunctional effect of breaking the link between academic research and societal utility-a link of central importance to the [Research Group]'s applied [science] mission' (Tuunainen 2005a: 200). In the immediate aftermath of those initial developments, the Research Leader 'resigned from the position of [academic] project leader' (Tuunainen 2005a: 199), researchers at the Spin-Off Company and the academic team of the Research Group 'concurred in prohibiting the use of each other's [research] results', and the Spin-Off Company's chief executive proclaimed that his company 'was [no longer] interested in commercializing the results of the [Research Group]'s academic projects' (Tuunainen 2005a: 200). As the final chapter of this failed collaborative innovation hybrid, and as soon as '[b]y the end of the year 2000, the [Research Group] had brought all of its academic projects to an end' (Tuunainen 2004: 32) after which 'the Spin-Off Company became a fully independent private entity' (Tuunainen 2005a: 201) 'with no direct ties to the university' (Tuunainen 2005a: 173). The Research Group itself 'de-grouped', and the Research Leader 'resigned her [academic] post [at the university in order] to work for a large multinational corporation in the United States' (Tuunainen 2005a: 201).

\section{Analysis and discussion}

The demise of the Hybrid Firm in the Tuunainen case study-a 2-year, largely unplanned, haphazard experiment in collaborative hybrid research innovation-is far from being an isolated case. Rather, it seems entirely consistent with (if not, emblematic of) the larger observation that 'a great deal of cross-sector research collaboration takes place between individuals and institutions informally and without external policy intervention' (Garrett-Jones et al. 2013: 84; emphasis in original). Indeed, as the Hybrid Firm in the Tuunainen case study exemplifies, there is regularly a complete absence of any 
advance legal planning for purposes of organising hybrid intermediary firms: The University of Helsinki is a long-established, stable organisation set in its ways-in the public realm, for public, non-profit purposes and by public initiative. The Spin-Off Company has also been organised and institutionalised, in a premeditated fashion, when it became opportune to do so, and with separate legal identity and recognised interests-by private ordering, for private, for-profit ends and as an exercise of strictly private entrepreneurial activity. The Hybrid Firm, however, is left to its own default devices (whatever such legal statutory defaults may have been under Finnish contract and/or for-profit/non-profit organisation laws-for example, under US business organisations law, the Hybrid Firm would, most likely, have constituted a for-profit partnership between the University of Helsinki and the Spin-Off Company, even if such legal partnership was formed unintentionally and without express agreement, thus, based entirely on the dealings and interactions of those two parties). In other words, the Hybrid Firm is operationally, functionally, institutionally and legally unorganised and noninstitutionalised-not just under-organised and under-institutionalised but unorganised and non-institutionalised-in every respect that matters for the efficient and sustained organisation and governance of intermediation tasks that should lie at the very heart of the Hybrid Firm. Without any advance (legal) planning among the helices to address and attempt to mitigate future dissension ex ante, without any precedential spin-off venture undertaken by the University of Helsinki at the time that could have served as an organisational blueprint and roadmap for the department, the New Chair, the SpinOff Company and the Research Leader, and without any clear-cut university rules and other legal regulations in place that addressed the myriad financial, operational, governance and legal issues relevant to the blurring of the boundaries within the Hybrid Firm (Tuunainen 2005b: 290-291), 'the concern for clean administrative boundaries emerged immediately' (Tuunainen 2005a: 188) at the department level after the SpinOff Company was established, and the 'attempt to hybridize the public and private activities [of the Research Group was] willingly resisted by [university] administrators' (Tuunainen 2005b: 292; see also Tuunainen (2002: 41)). Arguably, then, the university's non-intermediated absorptive capacity was at (or very close to) zero, making it impossible to 'move[] actors out of their institution-bound mind-set into a hybrid framework in which each internalizes some of the other's perspectives and "takes the role of the other" (Etzkowitz 2002: 125). Likewise, the Research Leader 'regarded the [Spin-Off Company] as an entirely private matter, with no ties to the university other than the temporary rental of laboratory space' (Tuunainen 2004: 56). Thus, notwithstanding (or, perhaps, because of) their relationship conflicts (Ranga and Etzkowitz 2013; van Geenhuizen et al. 2016), all parties seemed to have agreed, while still acting only upon their respective divergent personal and institutionalised agendas and never in the overall interest of the common, that the Hybrid Firm either was or should be considered non-existent. As a result, and with no more than 2 years in operation (Tuunainen 2002: 50), the Hybrid Firm—the very 'locus of innovation' (Todeva 2013: 273; see also Boon et al. 2011: 250)—was deliberately dissolved and 'de-hybridised.' Thus, the social and spatial innovation proximity that is generally seen as a crucial requirement for innovation intermediation (Bellgardt et al. 2014; Cantù et al. 2015; D'Este et al. 2012; Villani et al. 2016; Zhou 2014) was intentionally distanced, the permeability of (helical) boundaries that is generally regarded as quintessential for the effective transfer of technology (Pollard 2006: 150) was institutionally estopped, and the 'hybrid zone 
between academic and commercial logics' that intermediary organisations, as 'boundary organizations', are meant to manage (Villani et al. 2016), was unceremoniously abolished. The existence of the Hybrid Firm, while spanning and cross-cutting the public/private, nonprofit/for-profit boundaries between academic research and its commercialisation and 'sketch[ing], as it were, the "arena for transition"' (van Lente et al. 2003: 262), was putting too much 'strain' (or 'payload') on the traditional and strongly established boundary system so that-without any institutionalised locus and legally designated centre of intermediation - the only remaining intermediation mode palatable to the stakeholder-helices going forward became disintermediation (see Maharg 2016), which was executed all the way to its logical endpoint, namely, the complete separation of all prior collaborative endeavours with resultant non-intermediation. In the absence of any advance legal planning (including, in particular, advance legal dissension management) at the operational level of the Hybrid Firm, dissolving, splitting and 'going their separate ways' - together with the attendant total loss of all investments made by each helix into the Hybrid Firm - turned into the only viable option forward.

In describing the final outcome, Tuunainen (2005b: 291) concludes that the 'hybridization of the academic research with the private enterprise was not possible.' It should be noted, however, that this conclusion and factual outcome only holds true because of the un-organisation and non-institutionalisation of the Hybrid Firm. Assuming, in the double-negative, the absence of un-organisation and non-institutionalisation, one is left to wonder what would have happened (and, equally, what should have happened) if more emphasis and attention had been given to the legal organisation of the Hybrid Firm as a separate entity and 'player' among the helices-a player with its own legal status, identity and presence, its own representatives, its own decision-making and governance processes and its unique charge to consciously and deliberately provide tailored intermediation services to this particular collaborative, hybridised research project? For one thing, it seems evident that more organisational proximity (i.e. legal and functional membership in the same organisational Hybrid Firm entity) would have moderated the cognitive distance that existed between and among the University of Helsinki, the Spin-Off Company, the public funding agencies involved and the Research Group (see Johnson 2008; Villani et al. 2016). In particular, the Hybrid Firm could not have simply (i.e. legally) 'vanished into thin air'-by being brusquely split up between its academic and business operations-without its own, independent voice, influence, internal decision-making processes and, finally, its deliberate (and possibly intricate and protracted) dissolution and liquidation process. But all of this would have required a good amount of advance (legal) planning: every stakeholder in the Hybrid Firm's research collaboration made sunk investments of time, effort and money and, thus, at least, at the outset, wanted this particular hybridisation of academic research and private enterprise to succeed-in terms of both innovation and financial gains. Without innovation and financial success of the Hybrid Firm, such stakeholder would have never received any return on its respective investment from the team production among the university, the Research Group and the Spin-Off Company at the level of the Hybrid Firm. Thus, success in academic research as well as in its commercialisation was expected and was the overall goal-at least, in a diffuse, but shared manner-among the investor-participants of the Hybrid Firm. Indeed, the Research Leader was originally attracted to join the University of Helsinki from abroad through initial 
'funding from a major Finnish science-funding agency' (Tuunainen 2005b: 289), the Academy of Finland (Tuunainen 2004: 33) and, thereafter, the Research Group 'was receiving most of its funding from a major Finnish financing organization for applied and industrial research and development' (Tuunainen 2005a: 180), namely, the Finnish National Technology Agency (also known by its Finnish acronym: Tekes) (Tuunainen 2005c: 215; see also Dalziel and Parjanen 2012; Inkinen and Suorsa 2010). The Academy of Finland expressly required, as part of its original funding conditions, that the Research Group 'extended its collaboration networks from academic partners to international plant-breeding enterprises' (Tuunainen 2005a: 180). Similarly, Tekes 'stipulated that industrial collaborations had to be involved in projects it was going to finance[-as a result of which the Research Group] began seeking suitable partners' and, after negotiations with three potential partners, indeed, entered into a joint research and development venture with a Danish plant-breeding company in 1997 (Tuunainen 2002: 47-48). Furthermore, efforts at 'commercialization started to expand within the University of Helsinki [during the 1990s] as a result of new governmental policies that encouraged applied R and D by increasing the allowances distributed through the National Technology Agency (Tekes) [to universities]' (Tuunainen 2005a: 183). Finally, in setting up the SpinOff Company, the Research Group received the necessary capital investment from yet '[a]nother governmental agency, the Finnish National Fund for Research and Development, Sitra, [which] sought to create new companies out of the university research' (Tuunainen 2002: 50; see also Kivimaa 2014: 1373). Thus, on aggregate, the Academy of Finland, the Finnish National Technology Agency, the Finnish National Fund for Research and Development and the University of Helsinki (a publicly funded national university) all dedicated scarce public financial resources to the facilitation of innovation hybridity and its intermediation in order to jumpstart the first stage of collaborative, cross-sector research innovation at the Hybrid Firm-namely, to establish a tri-helical real-world research project and to enable inter-helical collaboration in academic research and its commercial development (the 'formation of collaboration', see Villani et al. (2016: 16)). But, then, after 10 years of intense research effort (1990-2000), multiple public grants and continuous public financial support, the second stage of collaborative, cross-sector research innovation turned out to be a complete 'institutional failure' (see Woolthuis et al. (2005)) in terms of its intermediation and sustainability. Such second (i.e. post-facilitation) stage should have constituted the successful implementation, growth and sustainability of the publicly funded and facilitated innovation hybridity-pursuant to continual and efficient means of triple helix intermediation within the Hybrid Firm (the 'performance of collaboration', see Villani et al. (2016: 16)). Instead, it seems obvious in the Tuunainen case study that, during this implementation phase, the 'complexity of intermediation in [the Hybrid Firm] innovation network[] [was systemically] underestimated' (Stewart and Hyysalo 2008: 296; see also van der Meulen et al. (2005: 3)). Accordingly, intermediation efforts by the individual helices at supporting and, perhaps, even growing the spontaneously (if not, accidentally) constituting Hybrid Firm were, at best, ad hoc (rather than planned) and non-coordinated (instead of institutionalised), thus, leaving each helix conveniently 'stuck' in its traditional, self-interest-driven, positional-bargaining mode which allowed it to ignore, 
in its entirety and against its own long-term best interest, the common, tri-helical cause and venture, namely, the Hybrid Firm.

As a result of assuming the absence of un-organisation and non-institutionalisation, one is also left to wonder how legal advance planning and the deliberate legal organisation and institutionalisation of the Hybrid Firm as a fully-fledged, fourth-party intermediary may have avoided its rapid demise? As a starting point, paraphrasing Tuunainen (2005a: 175), it is obvious that 'the boundaries separating the [Hybrid Firm] from the university [and the Spin-Off Company became] blurred except from a legal point of view' (emphasis added). Also, it bears reminding that the task of intermediation was to be 'done simultaneously in [three] distinct environments' (Tuunainen 2005a: 175): the university (with its physical research laboratory, the Department of Plant Production, its technology transfer and licensing office, its central university administration and other research support functions on campus), the Spin-Off Company (with its external management, its outside funders and its physical research facilities removed from the locus of academic research) and, in particular, the publicly funded Finnish technology and innovation agencies that provided both financial grants for the research collaboration as well as express encouragement for the commercialisation of any viable research resulting from such funding. Thus, as part of the funding conditions prescribed by the Academy of Finland, Tekes and/or Sitra, it would have been a simple, straightforward task to require that the funded academic (but potentially to be commercialised) biotechnology research of the Research Group should be conducted, for example, within a separately organised special-purpose, single-entity, smaller-scale CRC. Instead of an idle wait of 8 years of university-based academic research (1990 to 1998) before the Research Group's spontaneous commencement of commercialisation efforts through the formation of the Spin-Off Company, a Hybrid Firm entity could have been established from the very outset and legally separated from, but sponsored by, the University of Helsinki, the Research Group, any (later) Spin-Off Company and the public funding agencies in order to provide the most crucial services among such three helices and its stakeholders: dynamic, open-ended, open-textured and ongoing intermediation and hybridisation services that bridged both the formation and performance stages of triple-helix collaboration. Indeed, the funding provided by the Academy of Finland, Tekes and/or Sitra could have been made directly (and only) to such CRC entity, together with funding conditions (i) that all grant-relevant research (whether in furtherance of academic or commercial knowledge production and innovation) was to be conducted either at the CRC or under its direction, (ii) that all new, first-generation, intellectual property (IP) resulting from grant-relevant research was to be owned and primarily valorised by the CRC (i.e. not the university, not the Research Group, not the Research Leader or other individual researches and also not the Spin-Off Company), (iii) that such first-generation IP was to be licensed gratuitously to the university (with a right to sub-license to other non-profit academic institutions) for purposes of further academic-only research and as long as such research was not in competition with, or otherwise impeding any commercialisation of, the CRC's current or prior research, (iv) that such first-generation IP could also be licensed for market-rate fees to any spin-off company intending to explore commercial applications thereof (including, of course, the actual Spin-Off Company later formed by the Research Group) and (v) that any further academic-only research on the licensed IP leading to new, second-generation IP was to be licensed back to the CRC for purposes of additional research and commercialisation 
efforts. In other words, one is ultimately also left to wonder whether the efficiency, indeed, the survival of the Hybrid Firm in the Tuunainen case study would have been maximised significantly through the legal introduction and functional 'interjection' of a fourth, extrahelical and designated intermediation and hybridisation 'player.' The special-purpose, single-entity cooperative research centre suggested above (and by example only) would establish the Hybrid Firm legally and would establish the intermediation function of the Hybrid Firm institutionally. In its suggested format, most likely, the CRC entity would have been jointly owned and operated by the University of Helsinki (represented through one of its subdivisions, possibly, its science park organisation), the Spin-Off Company (which could have been formed right at the outset by the Research Leader and other members of the Research Group for purposes of representing their private personal interests with regard to commercialisation and profit-seeking from their publicly funded but, now, cooperative and fully hybridised research) and one or all of the public funding agencies involved (or any other public designee of the Finnish government as a stakeholder). In addition, the CRC entity would be structured to have its own institutionalised and, now, collectivised and internally intermediated decision-making and governance structure for purposes of providing external intermediation services to the three stakeholder-helices. And it would have its own separated identity, its own voice and its own designated and sui-generis intermediary role to play vis-à-vis and among the three helices.

\section{Inter-helical ad hoc self-intermediation vs. supra-helical institutionalised fourth-party intermediation}

Institutionally, the legal and functional organisation and separation of the Hybrid Firm, as proposed above on the basis of the Tuunainen case study, could be characterised as a treble paradigmatic shift in the organisation and institutionalisation of triple helix intermediation-namely, from inter-helical to supra-helical (or extra-helical (see Etzkowitz (2002)), i.e. 'outside of the [helical] partnership itself' (Johnson 2008: 495), thus, 'trans-organizational' (Todeva 2014: 1100)), from ad hoc to institutionalised and from self-administered to fourthparty administered (and, thus, professionalised) intermediation (Fig. 1). Overall, it also constitutes 'a shift from a "soft intermediary" to a "systemic intermediary" (van Lente et al. 2003: 259). To paraphrase the definition of the 'mode 3 systems approach' (Carayannis and Campbell 2009: 205; see also Carayannis and Campbell (2006, 2012)), triple helix intermediation, in this regard, becomes 'a multi-lateral, multi-nodal, multi-modal, and multi-level systems approach to the conceptualisation, design, and management of real and virtual [triple helix] modalities that catalyse, accelerate, and support the creation, diffusion, sharing, absorption, and use of co-specialised knowledge assets' for purposes of supra-helical organisation. Thus, in 'Triple Helix III' mode (Leydesdorff and Etzkowitz 1998: 196, 2000: 111), it is argued here that triple helix intermediation should move beyond the mere prescription of specific functional roles for each helix-actor and, therefore, beyond the resultant presence, if any, of the co-opetitive role hybridisation that may occur spontaneously and only temporarily without fourth-party intermediation among the three helices in such advanced intersectional helix mode. Rather, and in addition to 'the three strands form[ing] interorganizational bonds [and] provid[ing] multiple paths for inter-agency collaboration' (Metcalfe 2010: 505), it is further argued here that efficient intermediation requires a discrete, additional and suigeneris supra-helical realm that forms the 'emerging overlay' (Etzkowitz and Leydesdorff 


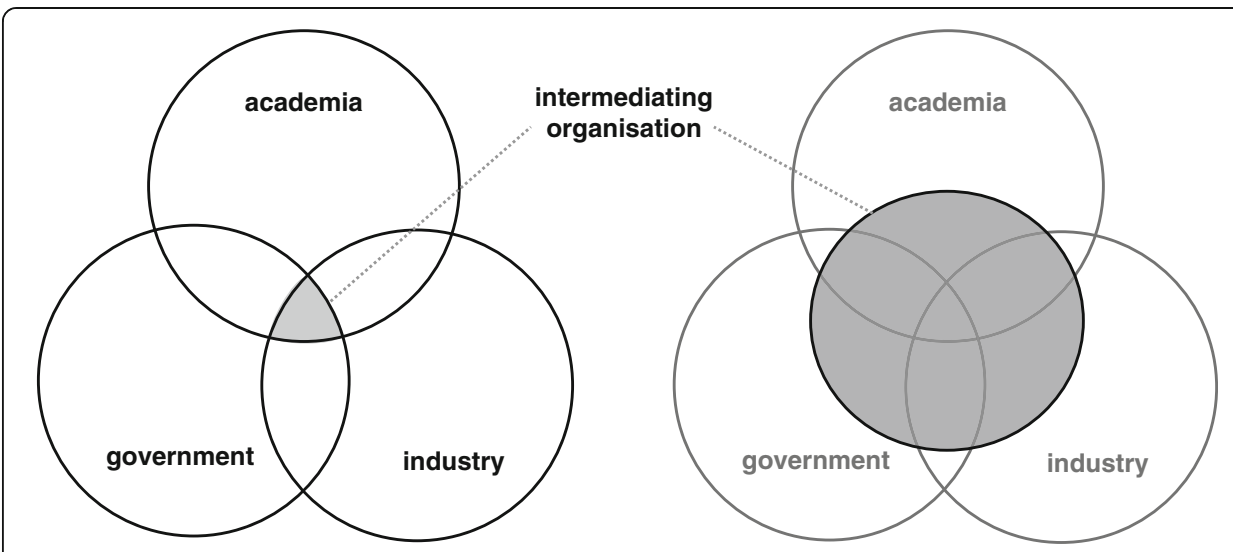

Fig. 1 Inter-helical, ad hoc self-intermediation vs. supra-helical, institutionalised fourth-party intermediation

2000: 112) of the triple helix infrastructure for innovation. Thus understood, mode 3 triple helix intermediation - in particular, in its most interspatially organised form — can be characterised as a conceptual and functional move from mere relational (i.e. contract-based) and inter-institutional co-opetition to organisational (i.e. entity-based) and supra-institutional co-opetition, thus, transcending the bi- and trilateral boundaries and intersections of the three helices. In other words, genuine trilateral triple helix networks, for purposes of organisational intermediation, constitute a sui-generis category of co-opetition (and, arguably, of triple helix intermediation research) in that they are characterised by a '[p]aradigm shift from "knowledge transfer" to "knowledge co-creation"' (Andersen et al. 2013: 8)-with the latter crucially facilitated and promoted through an independent (see Leyens (2011)), 'fourth-realm,' 'fourth-constituent,' 'supra-helical', thus, 'transinstitutional' (Benner and Sandström 2000) intermediation organisation. Accordingly, mode 3 triple helix intermediation requires a centralised coordination function (see Todeva (2013: 265))-beyond mere contractual coordination and more akin to a 'mediating hierarch' in team-production theory (Blair and Stout 2001: 421, 1999: 250; Cheffins 2015), an 'equilibrium solution' in corporate governance (Hermalin and Weisbach 2003: 7) or a 'superstructure organisation' in innovation research (Lynn et al. 1996: 98). In this regard, the triple helix thesis not only 'postulates a new institutional foundation for the development of innovations' (Bellgardt et al. 2014: 2) but, as part of a 'triple helix intermediation thesis', can be said to also postulate (if not, require) a new foundational institutionalisation of innovation within innovation.

\section{Modelling triple helix intermediation}

\section{Triple helix intermediation model}

As a primary systems-theoretical hypothesis and assumption for purposes of the legally institutionalised organisation of triple helix intermediation discussed above, this article posits that efficient triple helix collaboration in action critically requires, as a conditio sine qua non, fourth-party intermediation for purposes of optimising its formative and adaptive decision-making and governance processes. In other words, this article theorises, as an unalterable given for purposes of modelling triple helix intermediation, that the three helices are not self-sufficient, by and among themselves, to efficiently coordinate and mediate, through means of relational contracting only, ever-dynamic research knowledge 
(and related productive resource) equilibria as well as single-helix opportunistic selfinterest co-alignment equilibria (i.e. together, the overall triple helix process).

Instead, it is argued here that efficient triple helix intermediation requires an on-going fourth-party-administered (i.e. a triple-helix-process-embedded but non-helical) triple helix intermediation process-'independent' (Suvinen et al. 2010: 1386), 'outside' (Johnson 2008: 496) and non-derivative of, thus, separated from the individual procedural and substantive contributions of each of the three constituent helices as well as their direct bi- or trilateral helix-forming and helix-maintaining interactions and relations. Such intermediation process must serve as the functional, operational and legal framework for the control and coordination of triple helix intermediation in a given trilateral triple helix network over time (i.e. from cradle to grave). As schematically described in Fig. 2 below, the fourthparty intermediation process in application, thus, further requires the organisation of triple helix intermediation through a fourth-party actor and separate organisational structure-i.e. an intermediator-in order (i) to collect and disseminate relevant triple helix knowledge and other resources independently 'siloed' within each of the three helices, (ii) to organise and allocate such knowledge and resources to specific real-life triple helix applications and projects, and (iii) to, thus, coordinate, centralise and control the overall triple helix intermediation process. Finally, it is argued here that the fourth-party intermediation actor itself requires the institutionalisation of its own intermediation organisation through a mode 3 substructure, i.e. a distinct and separate legal entity (for example, a registered corporation/company) which organisationally and legally domiciles and controls the intermediator and, with it, the overall hybrid organisation of triple helix intermediation from the bottom up. The sphere- 2 intermediator and the sphere- 1 mode 3 substructure, in combination, constitute a 'superstructure organization' (Lynn et al. 1996: 98), a 'fourth type of organization within the triple helix environment' (Johnson 2008: 496) and what is generally referred to as an 'intermediating organization' (Metcalfe 2010). Thus, this sui-generis intermediating organisation (spheres 1 and 2)-which acts 'not only in terms of improving connectedness [among the helices but also assuming an] "animator" role of creating new possibilities and dynamism [within the triple helix]' (Howells 2006: 726) - may also be described as a helixerator, i.e. a nomenclatural combination of 'helix,' 'accelerator' and 'incubator'. It constitutes a separate, fourth-party intermediary organisation formed and deployed jointly by the helices for the sole and holistic purpose of accelerating and incubating, thus, innovating the innovation intermediation occurring within the triple helix. It is, therefore, also taking on a supra-helical 'leadership role[] to create collective benefits' (Dalziel 2010) and is, correspondingly, placed at its own 'locus of innovation [within] the facilitated [inter-helical] networks and partnerships' (Todeva 2013: 273). Thus situated, 'its intermediary services help [the helices] to overcome internal limitations [by extending each helice's] own resources for identifying technology commercialization opportunities' (Lichtenthaler and Ernst 2008: 1006).

\section{Additional premises and application of intermediation model}

Various derivative premises immediately apply with regard to the above core assumption and model of triple helix intermediation. Each of those premises can be contextualised, and an application of the model can be provided, by example, using the earlier discussed Tuunainen case study. For such purpose, it is assumed, as already suggested above, (i) that the Research Group's publicly funded biotechnology research at the University of Helsinki 


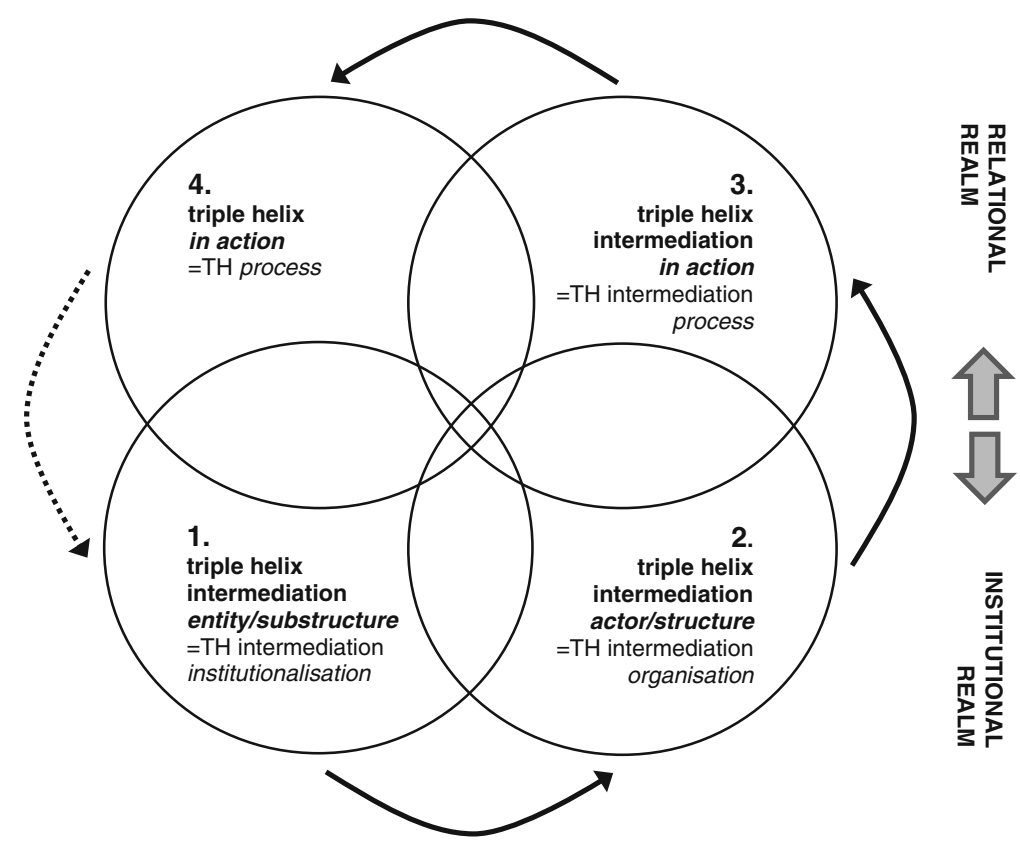

Fig. 2 A model of four organisational spheres of triple helix intermediation

would have been conducted, in the alternative and from the very outset, exclusively within the Hybrid Firm, and (ii) that such Hybrid Firm would have been separately organised as a stand-alone, special-purpose CRC entity (for example, a private registered corporation/ company) from the very moment it received governmental funding from the Academy of Finland and Tekes (and, possibly, also Sitra). Sponsored and jointly owned and operated by the University of Helsinki, the above public funding agencies (or their joint governmental designee) and the Spin-Off Company (which, as discussed above, could have been formed immediately by the Research Leader and the other members of the Research Group for purposes of representing their private personal interests with regard to the commercialisation of their research within the Hybrid Firm), the Hybrid Firm would now be independently organised as a sui-generis fourth-party sphere-2 intermediator and, in addition, would further be separately institutionalised through its own legal presence and identity as a sphere-1 mode 3 substructure, i.e. as a distinct and separate legal entity with its own institutional governance and decision-making bodies (in particular, a board of trustees and an executive management team) and with the ability to generate, legally own and commercialise its own assets, in particular, any intellectual property assets developed as a result of the Research Group's research work at the Hybrid Firm (hereafter, the 'IP Assets'). Such different legal ownership and treatment of the IP Assets within a now properly institutionalised Hybrid Firm fundamentally correlates with, and immediately responds to, one of the four major interest conflicts identified by Tuunainen (and discussed above) that directly contributed to the 'gradually deteriorating conflict' within the actual (non-organised) Hybrid Firm and its eventual demise, namely, the extent and treatment of 'the intellectual property rights of the [Research Group]'s researchers' (Tuunainen 2005a: 187; see also Tuunainen (2002: 51, 2004: 56, 2005b: 291)). Accordingly, it is also assumed in the following that, from the very outset of the now (hypothetically) fullyinstitutionalised Hybrid Firm in spheres 1 and 2, its three stakeholders (the University of 
Helsinki, the public funding agencies, and the Spin-Off Company representing the Research Group's personal interests with regard to the industrial application of its research) agreed to organise such institutionalised Hybrid Firm to also directly and exclusively own and commercialise all IP Assets (for example, national and international patents) which, in the future, would derive from the Research Group's biotechnology research at the Hybrid Firm. With these assumptions, the following additional premises and applications of the above intermediation model can now be discussed more fully:

First, triple helix intermediation is a multilevel and multiplex process. Each of the four spheres relevant to triple helix intermediation-the triple helix intermediation substructure/entity (sphere 1); the triple helix intermediation actor/intermediator (sphere 2); the triple helix intermediation process (sphere 3); and the triple helix process itself (sphere 4)-supports the next-order level of intermediation functionality. As an institutionalised intermediation agent and substructure (sphere 1), the intermediator entity domiciles, intermediates, facilitates and frames the overall organisational and functional intermediation structure (sphere 2). Such hybrid organisational structure and intermediation actor, i.e. the intermediator as a now organisational intermediation agent, facilitates and intermediates the experience of triple helix intermediation (sphere 3) which, in turn, facilitates and intermediates the overall triple helix experience (sphere 4). Assuming that the Research Group's biotechnology research at the Hybrid Firm would now produce its first patentable technology, three basic questions present themselves: (1) Should the technology be patented in the first place, i.e. should it become legally created and recognised as an IP Asset of the Hybrid Firm (hereafter, 'Question 1')? (2) Should the technology, once a patented IP Asset, be exploited and commercialised in any way and, if so, in which particular way or ways (hereafter, 'Question 2')? (3) Finally, if commercially exploited, to whom should the economic gains from the commercialisation of the IP Asset accrue (hereafter, 'Question 3')? Given the additional assumption made above that the sphere-1 intermediation substructure, i.e. the CRC entity, is set up to directly and exclusively own all IP Assets deriving from the Research Group's research work, each of those three questions will now require some substantial amount of intermediation involving all four spheres: Within the triple helix sphere-4 process, each of the three stakeholder-helices (the University of Helsinki, the public funding agencies and the Spin-Off Company) may have very different preferences for purposes of building a consensus around each of the three core questions. For example, regarding Question 1, such preferences could range from never patenting the technology and keeping it open source, to holding off with patenting the technology until it has generated additional applications and second-generation technologies through future internal research at the Hybrid Firm, to patenting the technology immediately and in as many jurisdictions as possible in order to maximise its early commercialisation. Once an inter-helical consensus on Question 1 is intermediated in sphere 4 and, as a result, patenting were to be pursued, Question 2 preferences can now range from never commercialising the technology (thus, merely protecting and controling exclusive access to the technology for the Hybrid Firm through patenting), to fully and immediately commercialising the technology (for example, by licensing it at market-rate fees to the SpinOff Company or any other industrial party), and to any viable option in-between. Finally, if commercialisation were to be pursued by intermediated inter-helical consensus achieved in sphere 4, Question 3 preferences among the helices may range from completely re-investing the economic gains of commercialisation back into the Hybrid 
Firm (for example, to self-finance further research by the Research Group), to fully distributing those gains to the three stakeholders of the Hybrid Firm (where they then could be used by each stakeholder for personal purposes entirely unrelated to its involvement with the Hybrid Firm), and to, again, any viable re-investment/distribution constellation in-between. Thus, in result, each of the three helices has to engage the other two in bi- and trilateral consensus-building processes within sphere 4 in order to achieve an overall decisional equilibrium (facilitated through the sphere-3 intermediation process) as to how to proceed with regard to a particular IP Asset that is now, based on their prior agreement, allocated and owned by the mode 3 substructure in sphere 1 . However, irrespective of the equilibrium achieved eventually in sphere 4 as to all three questions, such sphere- 4 consensus among the helices can never directly control, decide and implement any action vis-à-vis the sphere-1 substructure-owned IP Asset. Rather, such decision-making and governance control remains the exclusive prerogative of the sphere-2 intermediator who, ultimately and, in particular, as the substructure entity's board of trustees and its senior management team, will be legally charged with effectuating the patenting, commercialising and gain distribution decisions on behalf of the Hybrid Firm (and with regard to the IP Asset owned by it on the sphere-1 entity level). Finally, the sphere- 2 intermediator will only make those respective decisions (often only in an incremental fashion rather than all at the same time) once it has fully established the requisite sphere-4 consensus for each of the above three questions through its engagement, organisation and control of the sphere-3 intermediation process.

Second, the organisation of intermediation among spheres 1 to 3 is, conceptually, a unidirectional process. Whereas those three spheres, in real-world application, will coevolve in an interdependent, multi-linear and recursive fashion (see Etzkowitz (2002, 2003a); Schlierf and Meyer (2013)), i.e. in 'open regulation' (Todeva 2013: 276), the notion of intermediary organisation developed here flows from the bottom up (i.e. along the path prescribed by the solid arrows in Fig. 2 above): from the entity (sphere 1-where the Hybrid Firm's IP Asset to be patented and commercialised is legally located) within, and on the basis of, which the overall intermediator organisation is developed (sphere 2-where the ultimate decision-making control over the IP Asset and its commercialisation is legally located, and where the organisational control over the sphere-3 inter-helical engagement and consensus-development process is functionally located) which, in turn, maintains the intermediation process (sphere 3-where, through such intermediary process, the inter-helical engagement and consensus-development is functionally achieved) which, finally, defines the engagement and interaction of the intermediator and the three helices within the triple helix in action (sphere 4-where, ultimately, the inter-helical consensus for the IP Asset's commercialisation is functionally achieved).

Third, the intermediation organisation in sphere 2 and the triple helix process itself in sphere 4 have no direct, bilateral overlap. In other words, their (indirect) nexus is rather created, thus, genuinely intermediated, by the institutionalisation (sphere 1) and the process (sphere 3 ) of triple helix intermediation organisation. Thus, the triple helix process (sphere 4) and the triple helix intermediator (sphere 2) are truly separate (and, as posited here, should be truly separated) from each other, making the intermediator both structurally and functionally independent, non-derivative and supra-helical. 
Accordingly, the sphere-2 intermediator-acting, in particular, as the board of trustees and the senior management team of the sphere- 1 substructure, and taking into account the intermediated sphere- 4 consensus for the IP Asset's commercialisation-now acts entirely independently on behalf of, and becomes exclusively accountable to, the (hypothetical) Hybrid Firm in making and implementing decisions as to the deployment and commercialisation of the IP Asset owned by such sphere-1 CRC entity (for example, by way of authorising and executing a patent license of the IP Asset to the Spin-Off Company). As a combination of this third and of the second premise above, it can further be noted that the feedback from the triple helix process (sphere 4) flowing to the intermediator (sphere 2) will be indirect and reversely intermediated, i.e. it will be provided through individual and often entirely independent engagements by each stakeholderhelix with the intermediator given that the three helices together lack any extra-helical structure and unifying persona in order to (re-)act una voce vis-à-vis the sphere-2 intermediator. Unlike the sphere-2 intermediator's senior management team-who, legally, will be officers and employees of the sphere-1 CRC entity and, thus, can be expected to represent and act on behalf of the Hybrid Firm as a whole-most of the individual trustees on the sphere-1 CRC entity's board of trustees can be expected to be directly designated to their respective board positions by one of the three stakeholder-helices in order to serve as its respective boundary-spanning delegate in such highest internal governance body of the Hybrid Firm. As such, each stakeholder-helix will have available to it-entirely outside of the sphere- 3 intermediation process-a structural, indirect feedback loop that connects the sphere- 4 triple helix consensus-development process for the IP Asset's commercialisation with the sphere- 2 consensus-implementing and decision-making process for such commercialisation. Accordingly, it should also be noted that:

Fourth, the legal institutionalisation of triple helix intermediation organisation in sphere 1 allows all three stakeholder-helices to also intermediate the going-concern institutionalisation and continual renegotiation of their own intermediation. Therefore, stakeholder representatives on the entity, i.e. sphere-1 level of intermediation (in particular, as stakeholder-delegated trustees on the board of the registered corporation/ company that forms the mode 3 substructure) provide both single-helical and interhelical feedback within the substructure decision-making and governance processes and can, thus, critically influence the entire organisation and process of intermediation-an important feature of the second-order nature of institutionalisation (and of intermediation at large) which is emphasised by making the arrow between spheres 4 and 1 in Fig. 2 above non-solid, i.e. sui generis. In this regard, it may be further argued that the institutionalisation of triple helix intermediation also institutionalises boundary spanning, in particular, as between sphere 1 and sphere 4 of the intermediation model presented herein.

Fifth, given the joint influence and control of the triple helix stakeholders over the entire organisation of intermediation and, in particular, its 'pluricentric governance system' (Todeva 2014: 1093), it is also presumed that for purposes of commencing their triple helix intermediation, the three helices have to engage in pre-institutionalisation intermediation among themselves-often separately facilitated and intermediated by generic, non-helical, fourth-party actors/intermediaries during such pre-institutionalisation phase (for example, by legal, financial, research and management services providers (Dalziel 2010; Lamoreaux 
and Sokoloff 2002)) - for purposes of setting up the helixerator (spheres 1 and 2) and, thus, planning, coordinating and formalising their future institutionalised triple helix intermediation. As part of such proto-organisational, start-up intermediation, a common determination and enforceable agreement has to be achieved among the helices which is only assumed here for the hypothetical Hybrid Firm, namely, that any IP Assets generated through the Research Group's biotechnology research will accrue directly to the sphere-1 substructure which will, accordingly, become the sole legal owner of such IP Assets. None of the helices can achieve such outcome on its own. Indeed, when the University of Helsinki attempted to unilaterally assign and reserve IP rights exclusively to itself (by trying to force its public-servant researchers to assign their statutory rights to inventions accordingly), it single-handedly created a major conflict among the Research Leader (and other members of the Research Group), the Spin-Off Company and the university's central administration (as well as its Licensing Office). As discussed by Tuunainen (2005a: 187, 2002: 51, 2004: 56, 2005b: 291), such conflict contributed directly and fundamentally to the eventual demise of the actual Hybrid Firm. The fourth-party triple helix intermediation model presented herein would crucially support the avoidance of such outcome (and, most certainly, it would also support the fundamental mediation of all underlying interest conflicts at the Hybrid Firm post-investment) because it would force each of the helices-from 'square one' and as part of the advance legal organisation and institutionalisation of supra-helical intermediation-to engage first in inter-helical (self-)intermediation with the other two helices in order to achieve a 'pre-sorted' and 'pre-ordered' inter-helical consensus with regard to the allocation and assignment of future IP ownership rights resulting from the Research Group's work.

Finally, and sixth, the sui-generis nature indicated by the non-solid arrow running from sphere 4 to sphere 1 in Fig. 2 above is also a result of the distinct involvement of the government helix within all forms of triple helix intermediation. Here, the overall institutional design of triple helix organisation, including the fundamental organisational configuration of each of the three helices and of the mode 3 substructure itself, has-to varying degrees-been created, legally recognised, 'pre-set' and 'pre-selected' by governmental/regulatory action. In this regard, the government helix always assumes a meta-coordination function (Todeva 2013; see also Al-Tabbaa and Ankrah (2016)). Accordingly, triple helix intermediation and, in particular, the availability of a suitable and efficient (but also limited) set of organisational substructures (as either adaptable or specifically adopted legal entity forms) depends, in the very first place, on the government's 'invention' and recognition of such substructures as legally permissible, legally enforceable and legally independent organisational instruments for purposes of the necessary partitioning of rights, responsibilities and assets. In other words, whereas the intermediator (sphere 2) creates added value in the triple helix intermediation process by coordinating and synergising the demand-supply function of each helix, the intermediator itself as well as its sphere-1 substructure remains entirely dependent on the government's fundamental recognition and 'juridical-organisational' support of the intermediator's own organisational demand-supply function. It may therefore be claimed that the sphere- 1 mode 3 substructure not only critically matters-in the sense that a more optimised substructure will enable better intermediation processes in the long-term which will benefit the overall triple helix process and sectorial competition and, thus, optimise innovation outcomes-but that it should receive, as a generally 
scarce and complex resource, thorough regulatory attention and planning and, for such purpose, equally careful academic scrutiny, evaluation and augmentation.

\section{Analysis and discussion}

The current academic scrutiny and treatment of triple helix intermediation mostly concentrates on the substance of intermediation, i.e. on what intermediating organisations, in fact, do (Dalziel 2010; Metcalfe 2010; Suvinen et al. 2010; Todeva 2013). For example, Metcalfe (2010: 507) analyses three intermediational knowledge stocks and resultant flows of exchange (actors, resources, commerce) that 'connect the state, industry, and higher education to the intermediating organization [as] transactions that take place between and among formally defined organizational entities'. The exchanges may here become facilitated (and relationally, but not yet, institutionally intermediated) by so-called boundary spanners (Aldrich and Herker 1977; Todeva 2013: 265) who 'sit on two or three helices' (Todeva and Etzkowitz 2013: 11) or by generic, merely consultative and limited-task intermediary/brokerage organisations as, for example, banks and other financial intermediaries (Inkinen and Suorsa 2010; Lichtenthaler and Ernst 2008; Todeva 2013). Such substantive inquiries are obviously important. However, triple helix intermediation research should also focus on how intermediating organisations, in fact, do (or are supposed to do) what the do-either by default or by planned and optimised design. In other words, there should be (more) principled, theoretical and holistic inquiries into the process of triple helix intermediation irrespective of the particular object, objective or substance of the actual intermediating occurring among the helices. What intermediating organisations do and, in particular, how they do what they do must exist and be observable in general, i.e. irrespective of the particular factual substance and hybrid helical context of a specific triple helix project. Accordingly, (more) attention should also be given here to empirical and theoretical inquiries into the structural parameters and boundaries as well as the procedural and tactical 'nuts and bolts' that organise and optimise trilateral-network triple helix intermediation-in particular, for fully-fledged, stand-alone, fourth-party organisational intermediaries that operate exclusively within and for the benefit of a single triple helix gestalt (Håkanson et al. 2011). In this regard, the entire current 'blackbox' functions of (i) the intermediation process and the triple helix process (spheres 3 and 4), i.e. the external and relational organisational realm of triple helix intermediation, on the one hand, and (ii) the mode 3 substructure and the intermediator (spheres 1 and 2), i.e. the internal and institutional organisational realm of triple helix intermediation on the other hand, should be analysed and conceptualised more thoroughly and in foundational terms (see van der Meulen et al. (2005)). For example, with regard to modelling the first, external and relational realm of intermediation organisation, it seems appropriate to distinguish between triple helix hybridisation equilibria (within the sphere-4 triple helix process) and triple helix intermediation equilibria (within the sphere-3 triple helix intermediation process):

\section{Equilibria of triple helix organisation}

Figure 3 below schematically describes ten triple helix hybridisation equilibria that compose the highly charged organisational enterprise of triple helix intermediation. As Howells (2006: 724) has aptly concluded with regard to intermediaries more generally, 'they [not only] operate in a simple triadic "one-to-one-to-one" basis [but] are increasingly involved in more complex relationships, such as "many-to-one-to-one", "one-to-one-to-many", "many- 


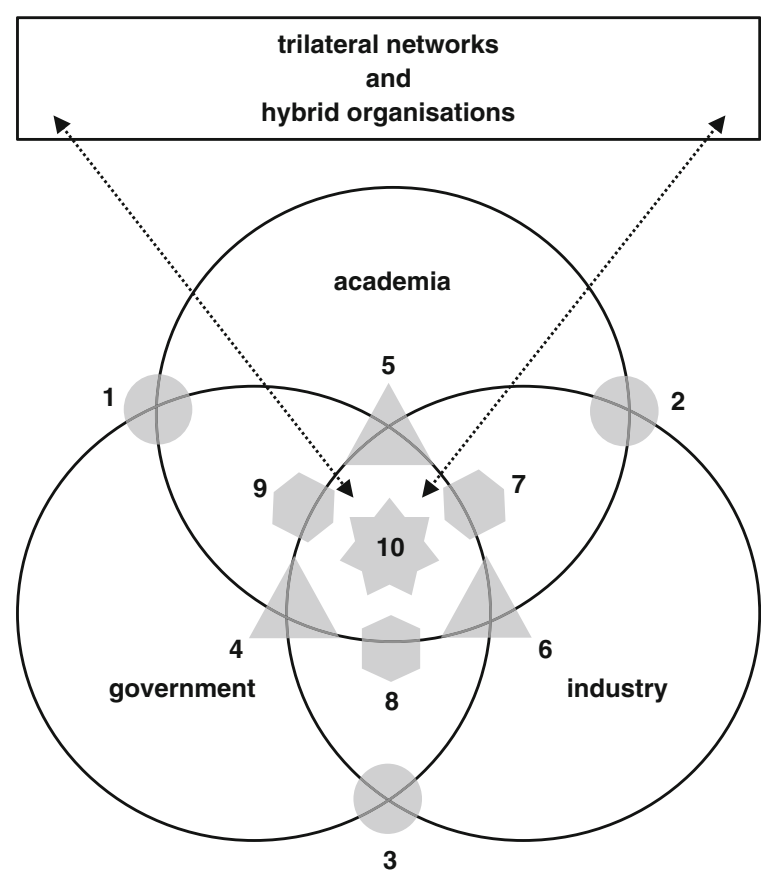

Fig. 3 Triple helix hybridisation equilibria (adapted from Etzkowitz and Leydesdorff (2000: 111))

to-one-to-many" or even "many-to-many-to-many" collaborations.' Thus, a triple-helix intermediary organisation is, by definition, a 'systemic intermediar[y]', i.e. 'a new type of intermediary organization that operate $[\mathrm{s}]$ at network or system level, in contrast to the more traditional intermediaries that tend to focus on bilateral relations (knowledge transfer) and the support of individual organizations (management support of small and medium sized firms' (van Lente et al. 2003: 249; see also Howells (2006: 725)).

In principle, all ten hybridisation equilibria either are or, at least, should be always and simultaneously engaged in the trilateral networks of the triple helix. In order to illustrate such 'concert' of hybridisation equilibria, the Tuunainen case study again provides a suitable contextual example and application. Each of the stakeholder-helices of the (hypothetical) Hybrid Firm discussed above may not only have fundamentally different preferences with regard to the patenting, commercialising and gain distribution of IP Assets (i.e. its preferences with regard to Questions 1 through 3 above), each stakeholder-helix will, by definition, also 'hybridise' such preferences along two (for current purposes, somewhat oversimplified) continua or sliding scales: For the industry-helix (i.e. the Spin-Off Company representing the industry-application and commercialisation interests of the Research Group members), it may be safely assumed that such helix is predominantly interested in applied research for purposes of generating private welfare gains. In other words, from the industry-helix perspective, any university or Hybrid Firm research that is conducted for its own sake (i.e. is merely conducted to generate new knowledge and irrespective of any motivations or concerns regarding its real-world utility, thus, is pure research) should be conducted-and any research, whether applied or pure, that is generating public welfare gains should do so-only as collateral and ancillary benefits of the primary generation of research outcomes that can be applied and commercialised for private profit. In partial contrast, 
the governmental helix (i.e. the three Finnish public funding agencies involved in the Tuunainen case study), in return for its financial investment to support the Research Group's scientific endeavours, can be expected to also strongly prefer applied research, however, with the predominant goal of generating public welfare innovation gains. Finally, the preference matrix for the university-helix (i.e. the University of Helsinki as a whole) must be assumed to be the most mixed among the three helices. Some university researchers may be most interested in pure research (because, for example, it suits their scientific path dependency), whereas university administrators and trustees may be most interested in applied research and only for purposes of generating private welfare gains in the form of additional revenue to the overall university as an educational institution (and irrespective of whether it is publicly or privately organised). In addition, some university researchers may align with university administrators and trustees and also be mostly interested in applied research but for their personal, private welfare gains (for example, the Research Leader and members of the Research Group) whereas other university researchers (who, for example, may prefer the generation of opensource technology) may be most partial to applied research but only for collective, public welfare gains.

Accordingly, triple helix hybridisation equilibria are composed of (and can be 'plotted' using Questions 1 through 3 above, as examples only, by) the following:

- three bilateral relational equilibria, i.e. one-on-one interactions and collaborations between two strands of the helix: (1) academia-government (where, for example, academia is indifferent about Question 1, and government prefers applied research that generates patentable IP Assets); (2) academia-industry (where, for example, academia strongly prefers pure research and is 'ideologically' opposed to any patenting under Question 1, and industry is interested in research that can create, at least, some private profits through IP Asset commercialisation); and (3) industry-government (where, for example, in answering Questions 2 and 3, industry is predominantly interested in IP Asset commercialisation that promotes its private welfare interests, and government, in contrast, strongly prefers the promotion of public welfare accruals, thus, public welfare innovation gains through IP Asset valorisation);

- three multilateral relational equilibria, i.e. two-on-one interactions and collaborations among two strands of the helix, working in coordination with each other and engaging the third strand: (4) academia-industry vis-à-vis government (where, for example, academia and industry have forged a consensus for applied for-profit research, and government pursues the promotion of applied non-profit research by either preferring open-source technology under Question 1 or only gratuitous licenses to the patented IP Assets for non-profit, non-industrial users under Question 2); (5) industry-government vis-à-vis academia (where, for example, industry and government jointly favour applied research so as to even reach Question 1, and academia prefers pure research and remains entirely indifferent to both Question 1 and the question of applied research more generally); and (6) academia-government vis-à-vis industry (where, for example, academia and government agree to commercialise IP Assets under Questions 1 and 2 but only for purposes of financing future public, non-profit academic research under Question 3, and industry requires to make some 
personal private profit for purposes of engaging with the academia and government helices in the Hybrid Firm's applied research to generate IP Assets);

- three multilateral relational equilibria, i.e. one-on-two interactions and collaborations among one strand of the helix engaging the other two strands which two may or may not coordinate with each other (if coordinated, these equilibria would be in reciprocity of the (4) to (6) interfaces, as applicable; if non-coordinated, they would constitute either a combined or a parallel (i.e. non-combined) engagement of single-strand efforts of academia at the (1) and (2) interfaces, industry at the (2) and (3) interfaces, or government at the (1) and (3) interfaces): (7) government vis-à-vis academia-industry (where, for example, government, preferring applied research for mostly public welfare gain, has to get academia to compromise on pure research preferences and industry to compromise on private profit preferences); (8) academia vis-à-vis industrygovernment (where, for example, academia has to accommodate at least some applied research, which both industry and government prefer, and find a compromise on the Question 3 public-private distribution of commercialisation gains, on which the preferences of industry and government diverge); and (9) industry vis-à-vis academia-government (where, for example, industry preferring applied research and private welfare gains has to find compromise with academia, which favours more pure research and more non-profit gain, and with government, which will only support applied research with public funding but also strongly values non-profit gain); and, finally,

- one single trilateral network equilibrium (i.e. meta-equilibrium) in which all three strands interact and collaborate three-on-three: (10).

It is important to note that any imbalance in just one of the ten dynamic triple helix hybridisation equilibria implicates, and immediately increases the 'payload' for, the entire balancing process that is the particular, intermediated trilateral network process in question and may, thus, single-handedly defeat the composite trilateral network meta-equilibrium from either becoming achieved in the first place or remaining sustainable thereafter (see Todeva (2013: 277)). In other words, one efficient trilateral network meta-equilibrium requires a 'concert' of (up to) ten constituent multilateral equilibria. Thus, the number-(10) equilibrium can only fully mature once all other active bilateral and multilateral equilibria have become synchronised and harmonised. It should also be noted that these ten hybridisation equilibria must be achieved for every substantive intermediation engagement and particular triple helix trilateral network project among the helices. Thus, every intermediated Question 1, Question 2 and Question 3 consensus for every IP Asset generated through the Research Group's biotechnology research within the Hybrid Firm engages (and re-engages) all ten hybridisation equilibria simultaneously. In addition, multiple trilateral network projects and intermediated project consensuses among the same three helix actors must be assumed to be highly interdependent unless in the rarest of circumstances (see van der Meulen et al. (2005: 3)). As a result, dynamics and '[f]lows between the trilateral networks are of particular relevance to the model of intermediating organizations' (Metcalfe 2010: 507). Thus, for purposes of 'creati[ng] a new overlay of trilateral networks and organizations from the interaction among 
the three helices' (Etzkowitz 2003a: 301), there also exists a meta-meta equilibrium-built on top of all deployed sets of ten-count trilateral network metaequilibria within the same university-industry-government triple helix.

\section{Equilibria of triple helix intermediation organisation}

It is this uncertain, open-textured, if not, fickle nature of triple helix trilateral networks which necessitates the additional, but separate, fourth balancing dimension and realm that constitutes the fourth-party-mediated (i.e. non-helical-party-conducted) triple helix intermediation process analysed here. Similar to a classical orchestra that requires a conductor or a team-production process in need of a 'mediating hierarch' (Blair and Stout 2001: 421, 1999: 250; Cheffins 2015), the sphere-3 triple helix intermediation process-called upon to critically support the sphere-4 triple helix hybridisation equilibria-requires an intricate synchronisation and balancing of participatory institutional interests among the three helices. As with any other multi-constituent wealth generation exercise, agency costs in the form of moral hazard and adverse selection are a ubiquitous challenge. More specifically, triple helix collaborations need 'to deal with asymmetric information and other transaction costs related to motivation and incentive problems with regard to each of the parties joining the collaboration, and uncertainty about future results of the joint projects' (Kodama 2008: 1226). In addition, always present social costs must become sufficiently mediated and internalised by means of the global intermediation equilibrium. In this regard, Fig. 4 below differentiates seven separate triple helix intermediation equilibria which must be developed and 'co-balanced' simultaneously within every sphere-3 intermediation process. Here, the intermediating organisation/organisational intermediary is placed in the middle of relationships between others' (Todeva 2013: 263), i.e. in-between and among the three helices, and, as a result, one will find:

- three single-helical intermediational equilibria, i.e. separate coordinating engagements and processes between the intermediating organisation and (1) academia, (2) industry and (3) government, respectively;

- three double-helical intermediational equilibria, i.e. separate coordinating engagements and processes among the intermediating organisation and (4) industry-government, (5) academia-government and (6) academia-industry, respectively (which three equilibrium levels each correlate with what Etzkowitz has described as 'hybrid organisations' (2003a) and Gibbons et al. as 'Mode 2' institutions (1994; see also Nowotny et al. (2001)); and, finally,

- one triple-helical intermediational equilibrium, i.e. the cumulative coordinating engagement and process among the intermediating organisation and all three helices at the same time: (7) (which equilibrium level correlates with what Etzkowitz has termed a 'tri-lateral network' (2003a)).

Looking at the external-realm balancing processes illustrated in Figs. 3 and 4 above in combination, it can further be posited that the aggregate effect of seventeen 'potential unit[s] of analysis' (Metcalfe 2010: 507) —namely, ten triple helix hybridisation equilibria within the sphere-4 triple helix process and seven triple helix 


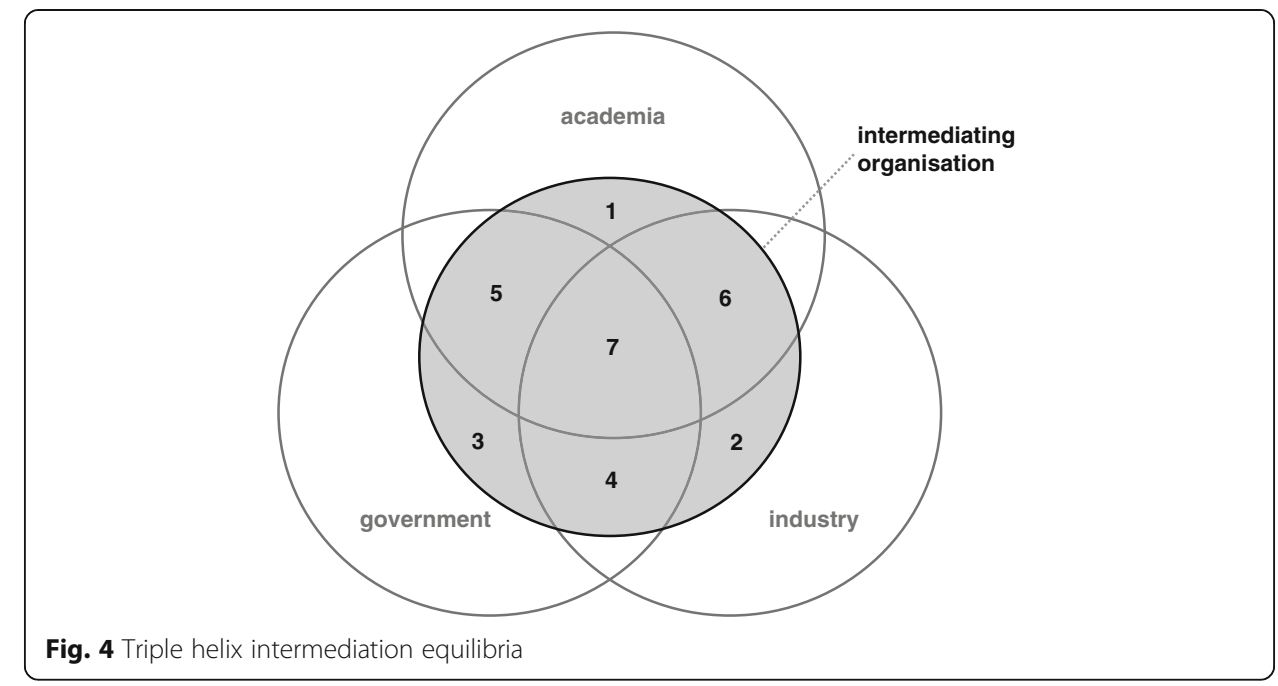

intermediation equilibria within the sphere-3 triple helix intermediation proces$\mathrm{s}$-puts a significant organisational burden on the intermediating organisation and its internal processes. In this regard, the nature, role and functionality of fourthparty intermediation organisations must be much more than merely 'serving as interorganizational bridges between universities, industries, and governments' (Metcalfe 2010: 504; see also Shohet and Prevezer (1996)). Because of the complexity (Leydesdorff 2000; Suvinen et al. 2010; Todeva 2013) and multiplicity-and, thus, also the resultant opacity-of organisational intermediary processes, the internal organisational realm of triple helix intermediation, i.e. the inner workings of the intermediation organisation (spheres 1 and 2), seems significantly more difficult to analyse and conceptualise theoretically in general, hence, context-nonspecific terms. Here, in particular, more empirical research would appear highly beneficial-even for the mere purpose of better crystallising future research agendas. What can, however, already be posited at this juncture is that the internal procedural intermediation equilibria can be expected to correlate, to a large extent, with the respective legal setup and formalisation, hence, institutionalisation of the intermediator and, in particular, the mode 3 substructure. In other words, if organisation matters for purposes of optimising efficient triple helix processes, then how we institutionally organise and structure the intermediating organisation itself (spheres 1 and 2) should matter at least as much (see Klerkx and Leeuwis (2008)). And to the extent that triple helix trilateral networks and their intermediation are a form of novel operational hybridity in innovation, such phenomenon should also necessitate an inquiry into whether an innovative and original organisational-including an innovative and original legal-hybridity in its intermediation is evolving and should be further developed. In Metcalfe's words (2010: 507), it is, after all, the intermediating organisation that 'is the primary organizational unit of analysis and the focus of inquiry.' A first (and, admittedly, only rough) assessment of what would be involved in such analysis and inquiry and how both traditional and more recent, nontraditional legal organisations could be modified, adapted and (re-)modelled for purposes of triple helix intermediation is undertaken-in brief and broad strokes only-in the following part. 


\section{Modelling legal intermediary organisation \\ Legal organisation of triple helix intermediation}

The legal organisation of multi-constituent revenue-seeking endeavours not only matters, but remains-for a large number of reasons (among others, predictability, enforceability, participation rights and responsibilities, resource allocation, asset partitioning, and the accounting, distribution and taxation of profits) - a core necessity for efficient collective productivity. Legal organisation happens-either proactively and by design (i.e. through proper advance planning) or reactively and by default (i.e. through post-investment statutory or common-law 'gap-filling' of incomplete contracts). Accordingly, for the current purpose of conceptualising triple helix intermediation organisationally, this article posits, as a secondary systems-theoretical hypothesis and assumption, that efficient triple helix trilateral network collaboration in action also critically requires an internal sphere- 1 intermediator 'meeting platform' (Suvinen et al. 2010: 1369) which, as an institutionalised legal substructure specifically and exclusively works the interstitial spaces of a given triple helix trilateral network. To date, such organisational function has not been accomplished (nor been sufficiently analysed) from a legal perspective. Rather, it appears that the legal organisation of universityindustry-government collaborations is pre-dominantly adapted from contractual, market-based mechanisms traditionally used for 'simple [commercial and arm's-length] supply-chain collaborations' (Fitjar et al. 2014: 2). For example, in the UK, the so-called Lambert toolkit, which has been in place since 2005 (Andersen et al. 2013; Eggington et al. 2013), is intended 'for universities and companies that wish to undertake collaborative research projects with each other' (UK Intellectual Property Office 2014) and 'to help [the] potential collaborators negotiate deals, lower the transaction costs of the negotiations, and provide examples of best practice' (Wrobel 2013). The toolkit includes five bilateral model research collaboration agreements, four multilateral model consortium agreements, a decision guide, and related guidance materials (UK Intellectual Property Office 2014). A 2013 research study (Eggington et al. 2013) commissioned by the UK Intellectual Property Office in order to empirically test awareness, adoption and overall utility of the Lambert toolkit among British universities and industry reported that the toolkit 'is most suitable [only] for a minority of university-business interactions,' further concluded that 'industrial support for the toolkit has been lacking [because] large companies are more likely to view the Lambert agreements as biased towards universities', and finally estimated that 'less than 10 or $15 \%$ by value of collaborative research between universities and business in the UK is based on a Lambert-like agreement' (Eggington et al. 2013: 3-4; see also Andersen et al. (2013: 45)). In other words, the UK government's contract-based and market-paradigmed solution to the intermediation of universityindustry collaborations turned out to be little used[,] seen as straightjacketing relationships between industry and academics, rather than enabling and supporting them[, and] not support[ing] open innovation' (Wrobel 2013).

From a theoretical perspective (and given the discussion above), this 'lack of traction' with regard to the promotion, standardisation and institutionalisation of triple helix collaboration and intermediation based solely on relational contracts-or, as in the Tuunainen case study above, the lack of traction based on the entire absence of any collaborative advance legal arrangements for the Hybrid Firm-must come at no surprise. Traditional methods of (quasi-)contractual 'co-adventuring' and coordination in 
order to accommodate 'post-postmodern' triple helix innovation interactivity among a large, and varied spectrum of potential university-industry-government actors must ultimately fail to account for and properly organise the multiplex hybridity that makes triple helix cooperation sui generis, in particular, in its most advanced forms of the supra-helical co-opetition discussed above (see Todeva (2013)). Contracts, whether express or implied, are tactical, outcome-oriented devices in order to control the future behaviour and performance of contract parties. They merely constitute a means in order to achieve the larger, specified ends of wealth-maximisation as they are 'particularised' and 'codified' by the contract parties within the four corners of each contract. Organisationally speaking, every contract may be conceptualised as 'anti-innovation' and 'anti-intermediation': it is never meant to create an open-ended, hybrid space for future creativity and innovation. Rather, its regulated object and objective is to deploy known, pre-existing and already fully identified tools and resources and to lock in reciprocal expectations and counter-expectations with regard to the future behaviour of all contract parties in their joint pursuance of the valorisation of such tools and resources. Furthermore, contracts-in particular, repetitive, long-term and multi-lateral ones (Todeva 2013) - are, by definition, incomplete and, in the absence of renegotiation, rely on post-investment gap-filling in order to remedy their organisational deficiencies and inflexibility. No such majoritarian-default legal gap-filling structure, however, exists for purposes of (quasi-)entrepreneurial, long-term collaborations. There is also no fallback, fail-safe legal default structure to functionally support intermediation organisations. Thus, collaboration, consortium and other framework agreements either require constant renegotiation when underlying circumstances or pre-collaboration assumptions change (see Garrett-Jones et al. (2013: 80)). Or, in the absence of re-negotiability (given the limitations imposed by transaction costs, opportunistic behaviour and bounded rationality), they become dead-letter private-ordering failures. Even then, as long as contract terms remain technically unexpired and in force, they continue to constrain parties (again, in the absence of unanimity for either contract modification or termination) to move on and explore alternative commercialisation efforts. Incomplete contracting (as well as the larger under-institutionalisation of intermediary organisations) is a cause of, not a solution for, incomplete and inefficient innovation. Intermediating organisations uniquely and purposefully position themselves to close the innovation gaps that result, inter alia, from performance ambiguity, goal incongruence and ambivalence (Dalziel 2010; Etzkowitz 2003a; Håkanson et al. 2011; Ouchi 1980). Accordingly, intermediation must be a status and end in itself-not merely a means that can be contractually 'corseted' and then mechanically and rigidly implemented according to a pre-set and static contractual plan. It may, thus, be posited that an institutionalised, legal intermediary organisation is necessary-again, as a conditio sine qua non-for purposes of providing a separate institutional structure, platform and framework within which the open-ended, open-textured and dynamic process of knowledge (in particular, tacit knowledge (Parker and Hine 2014)) innovation and valorisation can be organised and maximised efficiently. Unlike generic, non-helical, outside fourthparty actors and intermediaries (for example, legal consultants assisting in the negotiation and documentation of Lambert-toolkit agreements), this institutionalised, legal intermediary organisation, set up jointly by the three helices, is not limited to mediating, gap-filling and promoting specific functional aspects of the triple helix. Rather, it is 
organisationally charged-on a supra-helical meta-level-with accelerating the entire triple helix innovation process itself, thus, also promoting and innovating all of the future growth and integration potential of the overall triple helix network in application. In this regard, it can be said that the novel operational and functional hybridity of triple helix trilateral networks necessitates a corresponding one-of-a-kind organisational hybridity. In Etzkowitz's words (2003a: 308), here the 'Triple Helix ... becomes a platform for "institution formation", the creation of new organizational formats to promote innovation'-that is, even within the legal organisational realm.

\section{Legal hybridisation of triple helix intermediation}

Triple helix intermediation, by definition, constitutes a multi-purpose and multiinterest endeavour with a 'multi-organizational/multi-agency, multi-governmental and multi-sectoral governance' structure (Todeva 2014: 1100). Notwithstanding a primary and unifying interest and goal among the three helices in the form of innovation and revenue generation through knowledge commercialisation, each of the helices will require the triple helix process, the triple helix intermediation process and the overall intermediation governance structure in any given real-life triple helix collaboration to accommodate its respective secondary and individual, helix-specific, thus, disparate (i.e. non-unified and non-unifiable) interests and constituencies. Such secondary interests, inter alia, refract between (i) public and private welfare maximisation goals, (ii) horizontal (i.e. market-based) and vertical (i.e. hierarchical) collective organisation preferences, as well as (iii) for-profit and non-profit orientations and outcomes (Suvinen et al. 2010). As a result, advanced triple helix intermediation is a dynamic and perpetual meta-coordination exercise in which three, 'tri-symbiotic' foundational realms of organisational hybridisation constantly require to be co-aligned and inter-braided with each other:

\section{First realm of hybridisation: market/hierarchy}

Triple helix trilateral networks tread between market and hierarchy (Fitjar et al. 2014; Leydesdorff 2000). For the purposes of optimising real-world triple helix collaborations in a minimally regulated but also transaction-cost efficient manner, as discussed in the Tuunainen case study above, a sphere-1 mode 3 substructure should be formally formed or incorporated by the helices-thus, creating a special-purpose triple helix intermediation entity, i.e. a helixerator company. Such separate, stand-alone intermediation entity will benefit from both entrepreneurial advance planning (within its constituent documents, for example, its articles and bylaws, and its other foundational agreements among the helixerator company and its stakeholders, sponsors and owners) and the statutory default structures provided by applicable corporation or other organisational laws (see Fernández-Esquinas et al. (2012)). As such, the triple helix company is both an informal and an incorporated affair-a market/entrepreneurial device that transacts with its stakeholder-owners and a hierarchical/regulated structure that centralises and streamlines formative and adaptive decision-making for purposes of the continued survival, prosperity and innovation of the particular triple helix collaboration in question. It provides the sphere-1 'substructure organization' that produces the organisational innovation and institutionalisation for purposes of governing the overall 'superstructure organization' (Lynn et al. 1996: 98) that is the intermediary organisation 
(spheres 1 and 2 in combination) - which intermediary organisation, in turn, 'act[s] to provide collective goods to [the triple helix] members and help[s] to facilitate and coordinate the flow of information [and other critical resources to and among the helices]' (Howells 2006: 717). The helixerator company can, therefore, also be categorised in this regard as a trilateral hybrid between 'hierarchical', 'network' and 'cooperative coordination' (Todeva 2013) among its triple helix stakeholders.

\section{Second realm of hybridisation: public/private}

The triple helix and its intermediation, by definition, spans and cross-cuts a multitude of private and public boundaries (Metcalfe 2010; Ware 1989). Accordingly, it requires the accommodation of public and private welfare interests in a manner that seems unprecedented for purposes of even modern organisational law. Industry is quintessentially a private-realm endeavour and concern; government, of course, is its opposite. But even governmental revenue-generation and public welfare interests often move beyond the strictly public realm (as, for example, in a sovereign wealth fund). Thus, the governmental helix can be very much a private-realm and quasi-entrepreneurial actor. Finally, universities are usually incorporated and operate as either private or public entities. Still, one could point out that the secondary education of a given populace primarily remains a public good (thus, also resulting in private universities regularly being established for non-profit, tax-exempt ends). Accordingly, a single university-industrygovernment triple helix project can simultaneously blunt, blur and, if successful, converge multiple public-private hybridisation realms, all of which transcend once clearly established sectorial dyads and resultant organisational dichotomies (for example, private, taxed corporations for industry, municipal, non-taxed corporations for government, and non-profit, tax-exempt corporations for universities and other educational institutions).

\section{Third realm of hybridisation: for-profit/non-profit}

Finally, triple helix collaborations also merge for-profit and non-profit objectives and motivations. Eventually, all of these collaborations are expected to make money for their stakeholders, i.e. to generate sufficient income to finance current and future activities and to 'facilitat[e] increases in their [stakeholders'] viability, growth, [and] profitability' (Dalziel and Parjanen 2012: 119). The three stakeholders, however, will have very different expectations and preferences as to how and in what form such income should individually accrue to them. In contrast to the general non-profit assumption in the literature for designated intermediating organisations (for example, Dalziel 2010; Suvinen et al. 2010; compare Dalziel and Parjanen 2012; Klerkx and Leeuwis 2008), it is also assumed here that all three helices, as sponsors, members and owners of the helixerator mode 3 substructure, prefer to receive respective pro-rata shares from the financial payoffs of their joint research valorisation (in order to then fund their respective individual, single-helical, non-shared purposes). This third hybridisation realm is already a rather complex matter in the context of legal organisation. On the one hand, business corporations are designed to not only generate revenue for the common corporate interest but to also generate income that will allow individual profit-sharing by stakeholder-owners-such personal profit shares can then be used by each stakeholderowner for its own respective purposes, for example, by the university-helix for 
reinvestment into more academic research and research infrastructure. On the other hand, non-profit corporations are prohibited by law to allow any of its participants to receive any form of direct (i.e. de lege) or indirect (i.e. de facto or constructive) profit share. Here, any revenue surplus has to strictly benefit (and, if spent, be reinvested into) the common-it can never be released as a profit share to the individual, constituent parts. Vice versa, non-profit corporations are designed to engage in non-profitable, empathy-based, public-good activity and to not create and maximise private wealth; in contrast, business organisations are not supposed to consciously engage in activities that, in the long-term, will see them lose money and not generate profits for their investor-owners, even when doing so would directly benefit a public good.

\section{Hybridised legal organisation: second-generation legal hybrids}

As is argued here, the legal organisational mode 3 substructure for triple helix intermediation has to accommodate and institutionalise such multi-layered organisational hybridisation and resultant governance structure (Todeva 2013). It will require, inter alia, (i) a designated, standing governing body (for example, a board of directors or board of trustees with representatives from each helix (see Fernández-Esquinas et al. (2012) that is institutionally charged with all fundamental adaptive decision-making and with the operational oversight of the entire intermediary organisation), (ii) a highly active and involved advisory body (for example, an advisory board drawing expertise and leadership from all three helices, in particular, through boundary spanners (Aldrich and Herker 1977), for purposes of institutionally supporting the policy and strategic decision-making and collaboration that is at the heart of the innovation intermediation conducted by the helixerator) and (iii) other institutionalised conduits, 'meeting platforms' (Suvinen et al. 2010: 1369), 'pipes and prisms' (Podolny 2001) and 'crucial nodes' (Landry et al. 2013: 431) that perpetually and dynamically facilitate a wide variety and diversity of consultative and evaluative exchange and 'opportunity and engagement' (Håkanson et al. 2011) processes among the helices within which, for example, the three flows of exchange (actors, resources and commerce) identified by Metcalfe (2010) can occur more broadly and more fully.

In this regard, triple helix intermediation research should also focus more on a very recent regulatory trend regarding the hybrid legal organisation of both private and public, both for-profit and non-profit activities within the same single legal structure and entity - an international trend which could provide important blueprints and organisational experience, if not, ready-made and adaptable entity choices for purposes of the sui-generis triple helix intermediary organisations discussed herein. Figure 5 below describes such legal hybridisation more generally. A first-generation hybridisation of legal organisations occurred many decades, if not, centuries ago: here, the private sector started to engage in public-welfare activities through tax-exempt, non-profit entities-a form of public/private non-profit hybridisation. Then, during only the last decade and as part of a regulatory campaign and policy intervention to stimulate social entrepreneurship and social innovation, various national jurisdictions began adding new legal entities to their statutory ledgers, allowing for a second-generation hybridisation of legal organisation by combining for-profit and non-profit purposes within the same legal, privately owned corporation/company-a form of private for-profit/non-profit hybridisation. Whereas the first-generation hybridisation used private goods to create public 


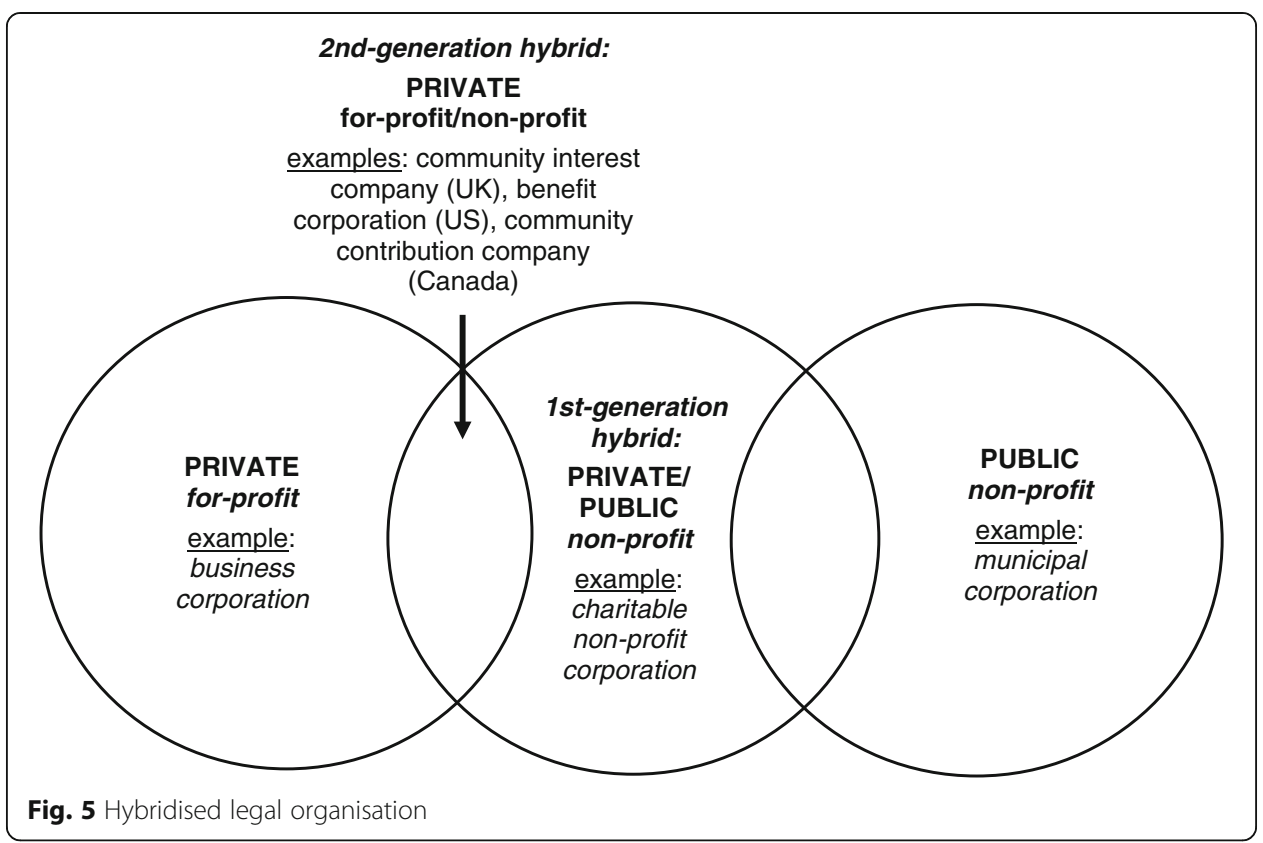

goods (with tax exemption for the organisation itself and tax credits for the organisation's sponsors), the second-generation hybridisation is meant to create public and private goods in tandem while using private investment through a modified corporation/ company format (and while fully taxing such hybrid activity). In the UK, the first of such private for-profit/non-profit hybrids, the so-called community interest company became available in 2005. In the USA, Maryland was the first state in 2010 to enact enabling legislation for so-called benefit corporations. And in Canada, British Columbia was the initial province to formally recognise so-called community contribution companies in 2013.

\section{Hybridised legal organisation: second-generation triple helix intermediaries}

Future research will be necessary in order to better evaluate whether the community interest company in the UK, the benefit corporation in the USA or the community contribution company in Canada could successfully be utilised as an efficient institutional intermediator and governance solution for real-world triple helix projects. In this regard, for example, a citation/search analysis conducted on 21 June 2016 using Google Scholar and searching for 'triple helix' and 'community contribution company' produced not a single matching result. What may already be pointed out here, however, is that each such hybrid legal organisation is already designed as a multi-helical hybrid structure: it operates beyond mere revenue/profit generation and is intended to accommodate both social innovation and social responsibility objectives of entrepreneurial activity. Thus, the public/private, for-profit/non-profit hybridity is built right into each such novel organisation's legal, institutional and teleological 'DNA'. Accordingly, each organisation could accommodate-without the organisational and institutional friction which hybridity unavoidably generates in traditional legal organisations (for example, business corporations, non-profit corporations, public corporations) - a broad spectrum of performance objectives, intra-, inter- and supra-helical participatory interests and institutional intermediary missions (in particular, with regard to knowledge innovation, 
private profit and public welfare co-generation). It should be noted, however, that the utilisation of each of such hybrid legal entities for purposes of institutionalising the internal workings of a triple helix intermediary organisation in practice will already constitute their innovative, 'off-label' adaptation and modification and may therefore generate certain stresses, inefficiencies and, possibly, failures as regards their organisational, i.e. statutory, design and default planning. Future empirical research is, therefore, also necessary in order to explore the adaptability (in theory) and adaptation (in practice) of community interest companies, benefit corporations and community contribution companies in real-world triple helix collaborations and their intermediation.

As described schematically in Fig. 6 below with regard to US-style corporations, the hybridisation of traditional entity forms (circles 1 through 4) yields either hybrid for-profit/ non-profit organisations-with either private ownership (overlap A) or public ownership (overlap B) - or hybrid public/private entities-with either non-profit purposes (overlap C) or for-profit purposes (overlap D) - but never both simultaneously (i.e. hybrid public/ private entities with hybrid for-profit/non-profit orientations). In contrast thereto, the triple helix and its intermediation is, by definition, a public/private, for-profit/non-profit dual hybrid. In other words, a combination of institutionalised triple helix intermediation and hybridised legal organisation is situated only where all four circles join together (overlap E), a unique, largely unexplored and legally non-organised public/private and forprofit/non-profit realm. Community interest companies, benefit corporations and community contribution companies are currently designed for for-profit/non-profit hybridity in the private realm only. They have not been promulgated to also accommodate the additional foundational cross-sectoriality of hybrid public/private governance structures.

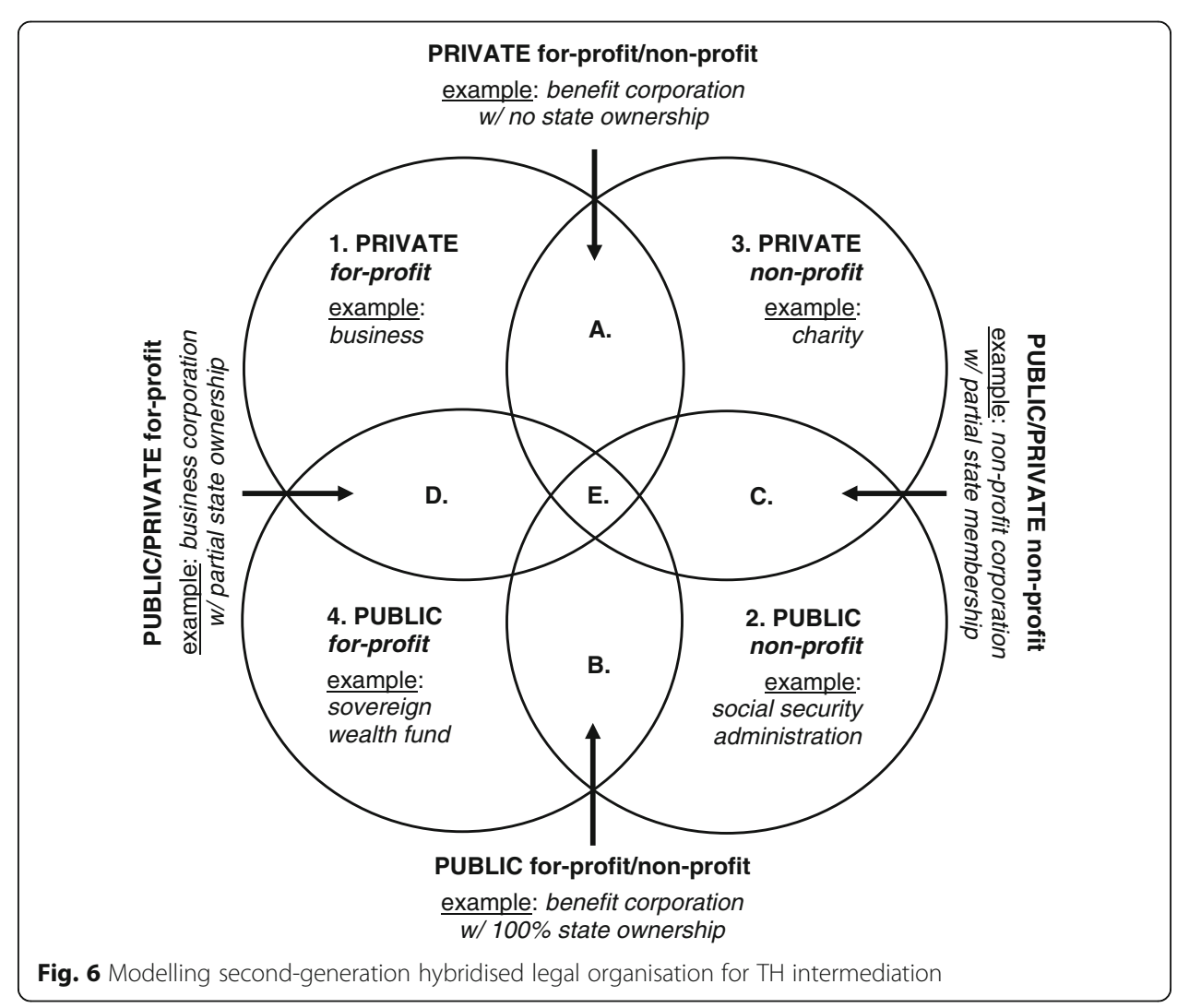


Additional research would therefore be beneficial in order to evaluate whether the abovedescribed social enterprise organisations (and, perhaps, other more traditional hybrid legal organisations, for example, cooperatives, associations, foundations and trusts) are further adaptable through private ordering in order to domicile, co-align and institutionalise the external intermediation equilibria within spheres 3 and 4 as discussed above, or whether-instead of, or in addition to, such efforts-more legal 'cross-breeding' may be necessary in order to make available next-generation hybrid legal entities (in overlap E) for purposes of optimising sui-generis triple helix intermediary organisations and their best practices. As Suvinen et al. (2010: 1385) have concluded more generally, '[ $\mathrm{t}$ ] here is justification for policy intervention to support the activities of intermediary organizations'. Traditionally and eo ipso, such policy intervention and 'normative control' (Todeva 2013: 265 ) is confined to the legal organisational realm.

\section{Conclusion and future research implications}

The triple helix is conceptualised as an evolutionary process (Etzkowitz 2003a; Etzkowitz and Leydesdorff 2000; Leydesdorff 2000). Similarly, triple helix intermediation itself can be characterised as an incremental and dynamic real-life process of trial-and-error experimentation towards a gradual evolution of best practices (see Klerkx and Leeuwis (2008: 273-274)). Notwithstanding such pragmatic prescription and, perhaps, the wisdom of solvitur ambulando, this article has posited that best practices (or 'good practices' (Etzkowitz 2006: 316)) of triple helix intermediation also require a designated, tactical, thus, suigeneris, supra-helical and institutionalised intermediating organisation-namely, and to paraphrase Dalziel's definition of innovation intermediaries, a separate 'organization[] within [the overall triple helix process and] organization[] that work[s] to enable innovation' (2010: 3; see also Dalziel and Parjanen (2012: 117-118)). Such institutionalised intermediating organisation, operating at the supra-helical meta-level of intermediation, engages in intermediation in intermediation-i.e. it intermediates the sphere-4 triple helix process discussed herein (as intermediation in innovation) and, simultaneously and in tandem, also intermediates the sphere-3 triple helix intermediation process (as innovation in intermediation). This article has further posited that the sphere- 1 mode 3 substructure discussed herein-i.e. a helix-independent and separately organised helixerator company which internally domiciles and institutionalises the triple helix intermediation structure-is an essential component for an efficient and advanced triple helix intermediation strategy. Finally, given that both 'demand and need for intermediary services are greater than the supply' (Suvinen et al. 2010: 1385), this article has identified and suggested multiple paths for further theoretical and applied research, including, a maiore ad minus:

- Principled, theoretical and holistic inquiries into the overall gestalt and 'fabric' of triple helix intermediation-i.e. irrespective of the particular object, objective, process or substance of any specific, real-world intermediation occurring among the helices and irrespective of the particular intermediary organisations involved (as, for example, university technology transfer and licensing offices; university centres of excellence; science, technology and innovation parks; research incubators; university spin-offs; cooperative research centres; R\&D consortia; technology institutes; and technology and innovation centres). Such inquiries would generally enrich the 
academic scrutiny and discourse of triple helix intermediation by broadening its current focus on the substance and outcomes of intermediation (i.e. on what intermediating organisations do) to also include more detailed and methodical examinations of the overall process and inputs of intermediation (i.e. of how intermediating organisations do (or are supposed to do) what they do).

- Foundational empirical and theoretical inquiries into what is currently still largely the 'black-box function' of the triple helix process and the triple helix intermediation process (i.e. the external, relational organisational realm of triple helix intermediation) on the one hand, and the 'black-box function' of the inner workings of the intermediator organisation and the mode 3 substructure discussed herein (i.e. the internal, institutional organisational realm of triple helix intermediation) on the other hand. Such bifurcated inquiries could be expected to promote a more systematic understanding - and, in turn, allow for an advanced modelling-of the structural parameters and boundaries as well as the procedural and tactical 'nuts and bolts' that organise and institutionalise trilateral-network triple helix intermediation.

- Quantitative and qualitative empirical research into the particular means of the organisation and institutionalisation of currently existing, functionally and legally separated, fourth-party helixerator-type intermediary organisations (as modelled and discussed herein). Assuming, arguendo, that the modernist architectural and industrial design principle of 'form follows function' also applies, by analogy, to the organisation and institutionalisation of triple helix intermediation, such empirical research would support and, also, focus and direct the overall discussion of whether fourth-party intermediary organisations are, indeed, a necessary or advisable ingredient of efficient triple helix intermediation and, if so, whether and to what extent they may constitute a non-plus-ultra efficiency equilibrium and governance solution for purposes of optimising triple helix intermediation by design.

- Systematic empirical and systems-theoretical examinations of the legal institutionalisation realm of designated, sui-generis intermediary organisations within three comparative realms: (i) across the same legal jurisdiction with regard to the same type of intermediary organisation (for example, among science, technology and innovation parks throughout the UK (see Minguillo et al. (2015)) or publicly-funded research centres in Northern Ireland (see Hewitt-Dundas and Roper (2011))), (ii) across different legal jurisdictions with regard to the same type of intermediary organisation (for example, among publicly-funded technology and innovation centres in the UK, the USA and Germany (see Hepburn and Wolfe (2014); Pollard (2006))) and (iii) across different types of intermediary organisations within the same legal jurisdiction (for example, university centres of excellence versus science, technology and innovation parks versus research incubators versus cooperative research centres in Canada (see Fisher and Atkinson-Grosjean (2002); Fisher et al. (2001); see also Todeva (2013))). Given that very few intermediary organisations are, legally, 'born equal', pursue identical intermediation goals, serve similarly-situated helices and, accordingly, operate, organise and institutionalise within only a very limited structural typology, the resultant vast variety and diversity of real-world triple helix intermediary organisations across the globe should be analysed on a comparative meta-level to better develop a phenomenology (and concomitant research commonality) of triple helix intermediation in terms of its (legal) experience, properties, convergence and efficiency. 
- Finally, first practical, theoretical and empirical research into (i) the adaptation and hybridisation of traditional legal entities (for example, associations, foundations, corporations and other non-profit or for-profit entities) and (ii) the adaptability of novel hybrid legal entities (for example, community interest companies in the UK, benefit corporations in the USA and community contribution companies in Canada) for purposes of legally institutionalising stand-alone intermediary organisations and providing efficient governance solutions for real-world triple helix collaborations (for example, science, technology and innovation parks, research incubators, cooperative research centres, national technology institutes, and national technology and innovation centres). Given the vast variety and diversity of triple helix innovation and wealth maximisation endeavours across the globe as well as the unique legal organisational design and domicile of each such endeavour (across a similarly varied and diverse spectrum globally), the legal institutionalisation of triple helix organisations should be scrutinised and evaluated in more detail-in particular, as regards the efficiency of their respective decision-making and governance equilibria-in order to support the emergence over time of best practices in the intermediation of 'innovation in innovation' (Etzkowitz 2003a) triple helix projects and to, thus, better understand and control the agency and social costs of such advanced triple helix collaborations.

\section{Additional file}

Additional file 1: Translation of the abstract into Arabic. (PDF $260 \mathrm{~kb}$ )

\section{Acknowledgements}

The research for this paper was conducted in part while the author was visiting at Queen's University Faculty of Law in Kingston, Ontario, whose hospitality and research support is gratefully acknowledged. I thank the anonymous reviewers, Henry Etzkowitz, Barbara Noah and, in particular, Emanuela Todeva for their encouragement and many valuable comments and suggestions on earlier drafts of this article. All errors are mine.

\section{Competing interests}

The author declares that he has no competing interests.

Received: 30 December 2015 Accepted: 6 October 2016

Published online: 24 October 2016

References

Aldrich H, Herker D (1977) Boundary spanning roles and organization structure. Acad Manag Rev 2(2):217-30

Al-Tabbaa O, Ankrah S (2016) Social capital to facilitate 'engineered' university-industry collaboration for technology transfer: a dynamic perspective. Technol Forecast Soc Chang 104(1):1-15

Andersen B, De Silva M, Levy C (2013) Collaborate to innovate: how business can work with universities to generate knowledge and drive innovation. Big Innovation Centre, London

Arvanitis R (2001) Challenges for the future: the evolution of science, technology and innovation policies. Paper presented at Science in Africa symposium, Somerset West, South Africa, 17-18 Oct 2001

Bathelt H, Feldman MP, Kogler DF (2011) Territorial and relational dynamics in knowledge creation and innovation: an introduction. In: Bathelt H, Feldman MP, Kogler DF (eds) Beyond territory: Dynamic geographies of knowledge creation, diffusion, and innovation. Routledge, London, pp 1-17

Bellgardt F, Gohlke J, Haase H, Parzonka R, Schicketanz J (2014) Triple helix and residential development in a science and technology park: the role of intermediaries. Triple Helix 1:10

Benner M, Sandström U (2000) Institutionalizing the triple helix: research funding and norms in the academic system. Res Policy 29(2):291-301

Blair MM, Stout LA (1999) Team production theory of corporate law. Virginia Law Rev 85(2):247-328

Blair MM, Stout LA (2001) Director accountability and the mediating role of the corporate board. Wash Univ Law Quart 79(2):403-447

Boon WPC, Moors EHM, Kuhlmann S, Smits REHM (2011) Demand articulation in emerging technologies: intermediary user organisations as co-producers? Res Policy 40(2):242-252 
Cantù C, Ylimäki J, Sirén CA, Nickell D (2015) The role of knowledge intermediaries in co-managed innovations. J Bus Ind Mark 30(8):951-961

Carayannis EG, Campbell DFJ (2006) "Mode 3": meaning and implications from a knowledge systems perspective. In: Carayannis EG, Campbell DFJ (eds) Knowledge creation, diffusion, and use in innovation networks and knowledge clusters: A comparative systems approach across the United States, Europe and Asia. Praeger, Westport, Connecticut, pp 1-25

Carayannis EG, Campbell DFJ (2009) 'Mode 3' and 'Quadruple Helix': toward a 21st century fractal innovation ecosystem. Int J Technol Manag 46(3/4):201-234

Carayannis EG, Campbell DFJ (2012) Mode 3 knowledge production in quadruple helix innovation systems: 21-century democracy, innovation and entrepreneurship for development. Springer, New York

Cheffins BR (2015) The team production model as a paradigm. Seattle Univ Law Rev 38(2):397-432

Coase RH (1937) The nature of the firm. Economica 4(16):386-405

D'Este P, Guy F, lammarino S (2012) Shaping the formation of university-industry research collaborations: what type of proximity does really matter? J Econ Geogr 13(4):537-558

Dalziel M (2010) Why do innovation intermediaries exist? Paper presented at DRUID summer conference, Imperial College London Business School, London, 16-18 June 2010

Dalziel M, Parjanen S (2012) Measuring the impact of innovation intermediaries: a case study of Tekes. In: Harmaakorpi V, Melkas H (eds) Practice-based innovation: Insights, applications, and policy implications. Springer, Berlin/ Heidelberg, pp 117-132

Eggington E, Osborn R, Kaplan C (2013) Collaborative research between business and universities: the Lambert toolkit 8 years on. UK Intellectual Property Office, Newport

Etzkowitz H (2002) Incubation of incubators: innovation as a triple helix of university-industry-government networks. Sci Public Policy 29(2):115-128

Etzkowitz H (2003a) Innovation in innovation: the Triple Helix of university-industry-government relations. Stud Sci 42(3):293-337

Etzkowitz H (2003b) Research groups as 'quasi-firms': the invention of the entrepreneurial university. Res Policy 32(1):109-121

Etzkowitz H (2006) The new visible hand: an assisted linear model of science and innovation policy. Sci Public Policy 33(5):310-320

Etzkowitz H, Leydesdorff $L$ (2000) The dynamics of innovation: from national systems and "Mode 2" to a Triple Helix of university-industry-government relations. Res Policy 29(2):109-123

Etzkowitz H, Ranga M (2011) Gender dynamics in science and technology: from the "leaky pipeline" to the "vanish box". Brussels Econ Rev 54(2/3):131-148

Etzkowitz H, Webster A, Gebhardt C, Cantisano Terra BR (2000) The future of the university and the university of the future: evolution of ivory tower to entrepreneurial paradigm. Res Policy 29(2):313-330

Etzkowitz H, Gupta N, Kemelgor C (2010) The gender revolution in science and technology. J Int Affairs 64(1):83-100

Fernández-Esquinas M, Giachi S, Pérez-Yruela M (2012) Building a triple helix corporation: organizational innovation for cross sector research collaboration in a catch-up region. Paper presented at Triple Helix X conference, Bandung, Indonesia, 8-12 Aug 2012

Fisher D, Atkinson-Grosjean J (2002) Brokers on the boundary: academy-industry liaison in Canadian universities. Higher Educ 44(3/4):449-467

Fisher D, Atkinson-Grosjean J, House D (2001) Changes in academy/industry/state relations in Canada: the creation and development of the networks of centres of excellence. Minerva 39(3):299-325

Fitjar RD, Gjelsvik M, Rodríguez-Pose A (2014) Organizing product innovation: hierarchy, market or triple-helix networks? Triple Helix 1:3

Fuglsang L, Eide D (2012) The experience turn as 'bandwagon': understanding network formation and innovation as practice. Eur Urban Regional Stud 20(4):417-434

Galindo PV, Vaz TDN, Nijkamp P (2011) Institutional capacity to dynamically innovate: an application to the Portuguese case. Technol Forecast Soc Chang 78(1):3-12

Garrett-Jones S, Turpin T, Diment K (2013) Careers and organisational objectives: managing competing interests in cooperative research centres. In: Boardman C, Gray DO, Rivers D (eds) Cooperative research centers and technical innovation: Government policies, industry strategies, and organizational dynamics. Springer, London, pp 79-110

Gassmann O, Daiber M, Enkel E (2011) The role of intermediaries in cross-industry innovation processes. R\&D Manag 41(4):457-469

Gibbons M, Limoges C, Nowotny H, Schwartzman S, Scott P, Trow M (1994) The new production of knowledge: the dynamics of science and research in contemporary societies. Sage, London

Håkanson L, Caessens P, MacAuley S (2011) InnovationXchange: a case study in innovation intermediation. InnovManag Policy Practice 13(2):261-274

Hepburn N, Wolfe DA (2014) Technology and innovation centres: lessons from Germany, the UK and the USA Technical report, Innovation Policy Lab, Munk School of Global Affairs, University of Toronto

Hermalin BE, Weisbach MS (2003) Boards of directors as an endogenously determined institution: a survey of the economic literature. Econ Policy Rev 9(1):7-26

Hewitt-Dundas N, Roper S (2011) Creating advantage in peripheral regions: the role of publicly funded R\&D centres. Res Policy 40(6):832-841

Hoppe HC, Ozdenoren E (2005) Intermediation in innovation. Int J Ind Organ 23(5/6):483-503

Howells J (2006) Intermediation and the role of intermediaries in innovation. Res Policy 35(5):715-728

Inkinen T, Suorsa K (2010) Intermediaries in regional innovation systems: high-technology enterprise survey from Northern Finland. Eur Plan Stud 18(2):169-186

Johnson WHA (2008) Roles, resources and benefits of intermediate organizations supporting triple helix collaborative R\&D: the case of Precarn. Technovation 28(8):495-505

Kivimaa P (2014) Government-affiliated intermediary organisations as actors in system-level transitions. Res Policy 43(8):1370-1380 
Klerkx L, Leeuwis C (2008) Matching demand and supply in the agricultural knowledge infrastructure: experiences with innovation intermediaries. Food Policy 33(3):260-76

Kodama T (2008) The role of intermediation and absorptive capacity in facilitating university-industry linkages: an empirical study of TAMA in Japan. Res Policy 37(8):1224-1240

La Porta R, Lopez-de-Silanes F, Shleifer A, Vishny R (2000) Investor protection and corporate governance. J Fin Econ 58(1/2):3-27

Lamoreaux NR, Sokoloff KL (2002) Intermediaries in the US market for technology, 1870-1920. Working paper 9017, US National Bureau of Economic Research

Landry R, Amara N, Cloutier J, Halilem N (2013) Technology transfer organizations: services and business models. Technovation 33(12):431-449

Leydesdorff L (2000) The triple helix: an evolutionary model of innovations. Res Policy 29(2):243-55

Leydesdorff L, Etzkowitz H (1998) The Triple Helix as a model for innovation studies. Sci Public Policy 25(3):195-203

Leyens PC (2011) Intermediary independence: auditors, financial analysts and rating agencies. J Corp L Stud 11(1):33-66

Lichtenthaler U, Ernst H (2008) Intermediary services in the markets for technology: organizational antecedents and performance consequences. Organ Stud 29(7):1003-1035

Lynn LH, Reddy NM, Aram JD (1996) Linking technology and institutions: the innovation community framework. Res Policy 25(1):91-106

Maharg P (2016) Disintermediation. Law Teach 50(1):114-131

Maughan CW, McGuinness K (2001) Towards an economic theory of the corporation. J Corp L Stud 1(1):141-180

Metcalfe AS (2010) Examining the trilateral networks of the Triple Helix: intermediating organizations and academyindustry-government relations. Crit Sociol 36(4):503-519

Minguillo D, Tijssen R, Thelwall M (2015) Do science parks promote research and technology? A scientometric analysis of the UK. Scientometrics 102(1):701-725

Nowotny H, Scott P, Gibbons M (2001) Re-thinking science: knowledge and the public in an age of uncertainty. Polity, Cambridge

Ouchi WG (1980) Markets, bureaucracies, and clans. Admin Sci Quart 25(1):129-141

Parker R, Hine D (2014) The role of knowledge intermediaries in developing firm learning capabilities. Eur Plan Stud 22(5):1048-1061

Pinto $P E$, Knights P, Hine D (2015) The design of publicly funded R\&D consortia: preliminary learnings from a longitudinal field-case study. Paper presented at DRUID15 conference, Rome, Italy, 15-17 June 2015

Podolny JM (2001) Networks as the pipes and prisms of the markets. Am J Sociol 107(1):33-60

Pollard D (2006) Innovation and technology transfer intermediaries: a systemic international study. Adv Interdisc Stud Work Teams 12(1):137-174

Ranga M, Etzkowitz H (2010) Athena in the world of Techne: the gender dimension of technology, innovation and entrepreneurship. J Technol Manag Innov 5(1):1-12

Ranga M, Etzkowitz H (2013) Triple helix systems: an analytical framework for innovation policy and practice in the knowledge society. Ind High Educ 27(3):237-262

Rivers D (2010) To join or not to join: Individual and sub-organizational factors affecting industry membership in universitybased cooperative research centers. Paper presented at Triple Helix VIII conference, Madrid, Spain, 20-22 Oct 2010

Roberts I (2004) The modern firm: organizational design for performance and growth. Oxford University Press, Oxford

Schlierf K, Meyer M (2013) Situating knowledge intermediation: insights from science shops and knowledge brokers. Sci Public Policy 40(4):430-441

Shohet S, Prevezer M (1996) UK biotechnology: institutional linkages, technology transfer and the role of intermediaries. R\&D Manag 26(3):283-298

Sieg JH, Wallin MW, von Krogh G (2010) Managerial challenges in open innovation: a study of innovation intermediation in the chemical industry. R\&D Manag 40(3):281-291

Slaughter S, Leslie LL (1997) Academic capitalism: politics, policies, and the entrepreneurial university. Johns Hopkins University Press, Baltimore

Stewart J, Hyysalo S (2008) Intermediaries, users and social learning in technological innovation. Int J Innov Manag 12(3):295-325

Suvinen N, Konttinen J, Nieminen M (2010) How necessary are intermediary organizations in the commercialization of research? Eur Plan Stud 18(9):1365-1389

Todeva E (2005) Governance, control and coordination in network context: the cases of Japanese Keiretsu and Sogo Shosha. J Int Manag 11(1):87-109

Todeva E (2006) Business networks: strategy and structure. Taylor \& Francis, New York

Todeva E (2010) Theoretical tensions between regulation, governance, and strategic behaviour in a federated world order. Int J Soc Econ 37(10):784-801

Todeva E (2013) Governance of innovation and intermediation in Triple Helix interactions. Ind High Educ 27(4):263-278

Todeva E (2014) Network management and governance. In: Alhajj R, Rokne J (eds) Encyclopedia of social network analysis and mining. Springer, New York, pp 1092-1101

Todeva E, Etzkowitz H (2013) The Triple Helix as a highly charged intellectual enterprise. Helice 2(3):8-12

Tuunainen J (2001) Constructing objects and transforming experimental systems. Persp Sci 9(1):78-105

Tuunainen J (2002) Reconsidering the Mode 2 and Triple Helix: a critical comment based on a case study. Sci Stud 15(2):36-58

Tuunainen J (2004) Hybrid practices: the dynamics of university research and emergence of a biotechnology company. Dissertation, University of Helsinki

Tuunainen J (2005a) Contesting a hybrid firm at a traditional university. Soc Stud Sci 35(2):173-210

Tuunainen J (2005b) Hybrid practices? Contributions to the debate on the mutation of science and university. High Educ 50(2):275-298

Tuunainen J (2005c) When disciplinary worlds collide: the organizational ecology of disciplines in a university department. Symbol Interact 28(2):205-228

UK Intellectual Property Office (2014) Guidance: Lambert toolkit. https://www.gov.uk/guidance/lambert-toolkit. Accessed 21 June 2016 
US Department of Energy, Office of Energy Efficiency and Renewable Energy (2015) Manufacturing innovation institute for smart manufacturing: advanced sensors, controls, platforms, and modelling for manufacturing. Funding opportunity announcement, number: DE-FOA-0001263, modification no. 0002. https://eere-exchange.energy.gov/ FileContent.aspx?FileID=f8a18a6c-0f01-4aad-a1 b9-88f62c67d515\&usg=AFQjCNFstKcpNK1vsE6b7je3GcF4Oh-VrQ. Accessed 21 June 2016

van der Meulen B, Nedeva M, Braun D (2005) Intermediaries organisation and processes: theory and research issues. Paper presented at PRIME workshop, Enschede, The Netherlands, 6-7 Oct 2005

van Geenhuizen M, Ye Q, Taheri M (2016) Hidden mediator roles of university spin-offs in Triple Helix networks. Triple Helix 3:5

van Lente H, Hekkert M, Smits R, van Waveren B (2003) Roles of systemic intermediaries in transition processes. Int J Innov Manag 7(3):247-279

Villani E, Rasmussen E, Grimaldi R (2016) How intermediary organizations facilitate university-industry technology transfer: a proximity approach. Technol Forecast Soc Chang (in press)

Wagner RW (2007) Academic entrepreneurialism and New York State's centers of excellence policy. ProQuest, Ann Arbor Ware A (1989) Between profit and state: intermediate organizations in Britain and the United States. Polity, Cambridge Weisz J, Hecksher SD, Ferraz FT, Mello JMC (2013) Spin-off or spin-in: a model for technology transfer and commercialization. Paper presented at Triple Helix XI conference, London, UK, 7-10 July 2013

Williamson OE (1975) Markets and hierarchies: analysis and antitrust implications. Free Press, New York

Woolthuis RK, Lankhuizen M, Gilsing V (2005) A system failure framework for innovation policy design. Technovation 25(6):609-619

Wright M, Clarysse B, Lockett A, Knockaert M (2008) Mid-range universities' linkages with industry: knowledge types and the role of intermediaries. Res Policy 37(8):1205-1223

Wrobel P (2013) UK plans to revise model agreement for university-industry collaborations. http://www.sciencebusiness. net/news/76213/UK-plans-to-revise-model-agreement-for-university-industry-collaborations. Accessed 21 June 2016

Yusuf S (2008) Intermediating knowledge exchange between universities and businesses. Res Policy 37(8):1167-1174

Zhou C (2014) Four dimensions to observe a Triple Helix: invention of 'cored model' and differentiation of institutional and functional spheres. Triple Helix 1:11

Submit your manuscript to a SpringerOpen ${ }^{\circ}$ journal and benefit from:

- Convenient online submission

Rigorous peer review

- Immediate publication on acceptance

- Open access: articles freely available online

- High visibility within the field

Retaining the copyright to your article

Submit your next manuscript at $\boldsymbol{\nabla}$ springeropen.com 